\title{
Human papilloma virus: A review study of epidemiology, carcinogenesis, diagnostic methods, and treatment of all HPV-related cancers
}

\author{
Maryam Soheili ${ }^{1}$, Hossein Keyvani ${ }^{2,3 *} \mathbb{C}$, Marzieh Soheili ${ }^{4,5}$, Sherko Nasseri ${ }^{6,7 *}$ (D) \\ Received: 1 Oct 2020 \\ Published: 22 May 2021
}

Abstract

Background: Human papillomavirus (HPV) infection is considered as the most common viral sexually transmitted infection worldwide. This poses an increasingly interdisciplinary medical challenge. Since there is vast scattered information in databases about HPV and the correlated diseases, we decided to collect useful data so that the experts can get a more comprehensive view of HPV.

Methods: In this article, HPV-associated diseases, prevalence, prevention, and new treatments are discussed. The retrieved articles reporting the latest data about the required information for our review were selected through searching in Web of Science, Scopus, Medline (PubMed), EMBASE, Cochrane Library, Ovid, and CINHAL with language limitations of Engllish and German.

Results: There are 2 groups of HPVs: (1) low-risk HPV types that can lead to genital warts, and (2) high-risk HPV types that are involved in HPV-associated oncogenesis. About $70 \%$ of all sexually active women are infected and most of these infections heal within many weeks or months. In the case of HPV-persistence, a risk of preneoplasia or carcinoma exists. These types of viruses are responsible for the existence of genitoanal, gastrointestinal, urinary tract, and head and neck tumors. There is still no definite successful treatment. The detection of HPV-related condylomata occurs macroscopically in women and men, and the diagnosis of the precursors of cervical carcinoma in women is possible by Pap smear.

Conclusion: For extragenital manifestations, there is no structured early detection program. Meanwhile, studies on HPV vaccines confirm that they should be used for the primary prevention of HPV-dependent diseases. However, we need more research to find out the real advantages and disadvantages of vaccines.

Keywords: Human Papilloma Virus, Cancer; Epidemiology, Warts, Vaccines, Virology, Diagnostic

Conflicts of Interest: None declared

Funding: None

*This work has been published under CC BY-NC-SA 1.0 license.

Copyright $($ Iran University of Medical Sciences

Cite this article as: Soheili M, Keyvani H, Soheili M, Nasseri Sh. Human papilloma virus: A review study of epidemiology, carcinogenesis, diagnostic methods, and treatment of all HPV-related cancers. Med J Islam Repub Iran. 2021 (22 May);35:65. https:///doi.org/10.47176/mjiri.35.65

Introduction

Sexually transmitted infections (STIs) are initially de-

Corresponding author: Dr Hossein Keyvani, keyvani.h@iums.ac.ir

$$
\text { DrSherko Nasseri, sherko.nasseri@muk.ac.ir }
$$

1. School of Kinesiology and Health Science, York University, Toronto, Canada

2. Department of Medical Virology, School of Medicine, Iran University of Medical Sciences, Tehran, Iran

3. Gastrointestinal and Liver Disease Research Center, Iran University of Medical Sciences, Tehran, Iran

4. Faculty of Medicine, Kermanshah University of Medical Sciences, Kermanshah, Iran

5. Human Revivification Society of Congress 60, Tehran, Iran

6. Cellular and Molecular Research Center, Research Institute for Health Development, Kurdistan University of Medical Sciences, Sanandaj, Iran

7. Department of Molecular Medicine and Medical Genetics, Faculty of Medicine, Kurdistan University of Medical Sciences, Sanandaj, Iran veloped by sexual contact and have a high rate of morbidi-

$\uparrow$ What is "already known" in this topic:

There are numerous papers in the field of sexual transmitted diseases (STDs), especially HPV. However, most of them do not have comprehensive data involving the main facts. Some of them have only evaluated the epidemiology or carcinogenesis or screening methods. And some have only assessed one type of cancer correlated with HPV. Thus, there is no distinct information among concepts.

\section{$\rightarrow$ What this article adds:}

This study presents comprehensive updated data about HPV, the laboratory methods, and all its correlated cancers. These combined data are highly useful for the clinicians and laboratory specialists. This is the main reason that we decided not to divide this article into several papers. The readers do not need to look for scattered information to find their required data. A vast part of the information is available in tables and figures that are easily reachable by the readers. 
ty and mortality worldwide, affecting $50 \%$ to $70 \%$ of sexually active individuals $(1,2)$. Human papillomaviruses (HPVs) are a large and diverse group of epitheliotropic double-stranded DNA viruses (3). There are up to 225 types of HPVs divi ded into 5 groups $(\alpha, \beta, \gamma, \mu$, and $v)$ (4). The exact classification of each group is shown in Figure 1. A subgroup of about 15 of the $\alpha$-types (high-risk (HR)-HPV types) can lead to invasive carcinomas $(5,6)$.

Persistent HPV infection is one of the important sexual transmitted diseases (STDs) associated with more than 5\% of all cancers in the world (7). In other words, globally more than half of all malignancies related to infection are caused by HPV (8). Approximately $90 \%$ of the HPV viruses clear or become dormant in 1 to 2 years after infection. Statistics show that the majority of women who had a positive test for a high-risk HPV serotype developed cervical cancer after 3 to 5 years (9). HPVs mostly cause nonpersistent acute infections. Hence, like other oncoviruses, there is a striking gap between the times of diagnosis of the chronic infection and its early stages (10). Some studies report that infection with at least 1 high-risk HPV will occur during the lifetime of $60 \%$ of sexually active individuals (11). They are often eliminated by the immune system within 1 or 2 years after exposure (12). The virus in the remaining cases that persists for a long time affords lesions that can bring malignancies (13). Therefore, early diagnosis of HPV infection and HPV induced lesions is highly important to prevent cancer development (14). In this review, we tried to collect all data about the prevalence, mechanism of action and carcinogenesis, the correlated disases as well as a brief overview about laboratory studies, screening, diagnosis, and therapies of each disease. This collection has been prepared by the newest data of valid databases and websites, such as Centers for Disease Control and Prevention (CDC) and human papillomavirus (HPV) centers. This information can help us to be aware of several factors when a patient with HPV comes to us for screening or treatment.

\section{Methods}

\section{Search Syntax and Search Strategy}

All original published articles were searched in international databases, including Web of Science, Scopus, Medline (PubMed), EMBASE, Cochrane Library, Ovid, and CINHAL to retrieve all articles reporting the latest data about epidemiology, diagnostic methods, and treatment of diseases related to HPV that were not discussed comprehensively in previous studies. A search of these databases was performed by the researchers with hand searching through the reference lists and gray literature. We searched from January 1985 to March 2020, with language limitation of English and German. All related components were related to the following keywords: "Human Papilloma Virus", "HPV", "Epodemiology", "Carcinogenesis", "Diagnostic methods", "Screening methods", "Treatment", "Cervical cancer", "Cervical neoplasm", "Cervical malignancy", "Vulvar and vaginal cancer", "Vulvar and vaginal neoplasm", "Vulvar and vaginal malignancy", “Anal cancer", "Anal neoplasm”, “Anal malignancy",'Esophageal cancer”, "Esophageal neoplasm”, "Esophageal malignancy", "Colorectal cancer", "Colorectal neoplasm", "Colorectal maliganany", "Prostate cancer", "Prostate neoplasm", "Prostate malignancy", "Urothelial cancer", "Urothelial eoplasm", "Urothelial malignancy", "Testicular cancer", "Testicular neoplasm", "Testicular malignancy", "Renal cancer", "Renal neoplasm", "Renal malignany", "Penile cancer", "Penile neoplasm", "Penile malignancy", "Head and neck squamous cell carcinoma", "Head and neck cancer", "Head and neck neoplasm", "Head and neck malignancy", "cutaneous squamous cell carcinoma", "Warts", "HPV Vaccines", and "HPV DNA Tests.

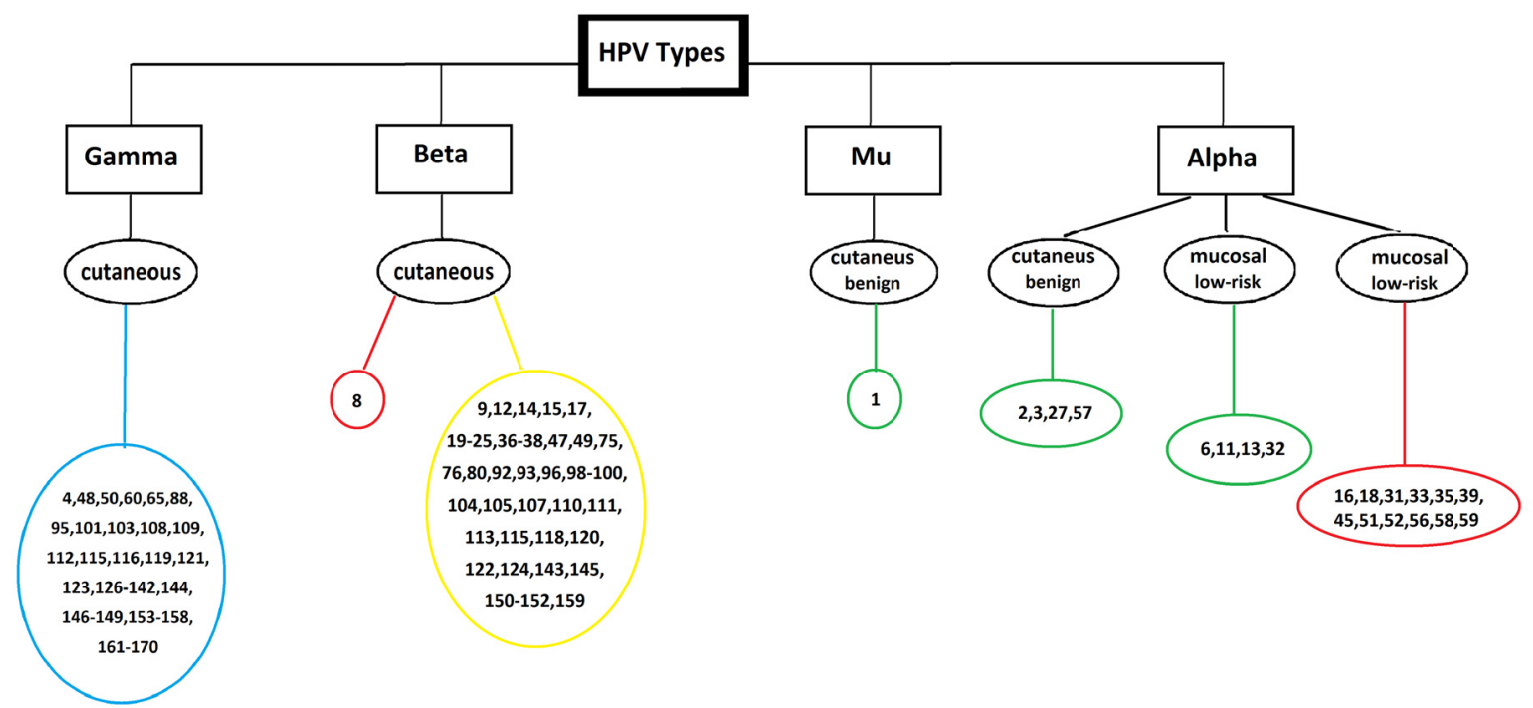

Fig. 1. HPV classification: Red color: High-risk HPVs, Green color: Low-risk HPVs, Yellow colors: probably high-risk HPVs, Blue color: Unknown 


\section{Screening and Selection}

The Reference Manager bibliographic software was applied to manage the searched citations. Duplicate entries were checked by considering the title of the published papers, authors, year of publication, and specifications of the sources types. In case of questionable records, the texts were compared. We reviewed the initial search results, and after reviewing each article by title and available abstract, some of the articles were excluded. Evaluating the papers under consideration was based on the inclusion and exclusion criteria by 2 researchers separately (Sh.N. and Maryam S.). About 546 papers were retrieved; 353 of which were selected and evaluated to extract the required information. In case of finding no data in the studies available in databases, we tried to apply valid websites such as HPV center or CDC that have been cited in references.

\section{Eligibility Criteria}

All observational studies that assessed the prevalence of HPV and related cancers, screening and diagnostic methods, and total therapeutic managements were included. We excluded duplicate citations, oral presentation, posters, and articles where their abstract and full-text were not available. The original articles and reviews were included.

\section{Data Extraction}

Three steps of assessment for titles, abstracts, and fulltexts were done. The full-text of each selected article was retrieved for detailed evaluation. Data were extracted using a checklist involving publication year, authors, type of cancer, laboratory tests, screening methods, diagnostic methods, and treatment. All steps from search to final data extraction were followed independently by 2 research experts (Sh. N., Marzieh S).

\section{Results}

\section{Epidemiology and Transmission}

About $50 \%$ to $80 \%$ of sexually active females will be infected with HPV during their lifetime (15). The estimated global HPV prevalence is $11.7 \%$. South Africa $(17.4 .0 \%)$, Eastern Africa (33.6\%), Eastern Europe (21.4\%), Western Europe (9.0\%), Eastern Europe (21.4\%), and Caribbean (35.4\%) showed the highest HPV prevalences $(16,17)$. Female sex workers (FSWs) are among the most susceptible groups to acquire HPV infection and develop cervical intraepithelial neoplasia and cervical cancer. In a meta-analysis done by Farhmand et al, it is demonstrated that the pooled HPV prevalence was 42.6\%. HPV-16, HPV-52, and HPV-53 were the most common high-risk HPV types found among FSWs (18). Since there are no definite antiviral treatments for HPV, the high prevalence of genital HPV has been a great concern in the world (19). Another research evaluating 645 sexually active innercity young females reported a cervical HPV prevalence of 54\% (20). Assessments of 12.7 million cancers occurring globally in 2008 showed that HPV infection is related to almost $100 \%$ of cervical cancers, $90 \%$ to $93 \%$ of anal canal cancers, $12 \%$ to $63 \%$ of oropharyngeal cancers, $40 \%$ to $64 \%$ of vaginal cancers, $40 \%$ to $51 \%$ of vulvar cancers, and $36 \%$ to $40 \%$ of penile cancers. Virtually $5 \%(610000)$ of the cases had HPV associated with anogenital or oral cancers. Nonmelanoma skin cancers are the increased risk of cutaneous HPV types. The initial risk factor for occurring the anogenital and oral HPV infection among males and females is sexual behavior (21).

\section{HPV Infection and Carcinogenesis}

HPV infection can be persistent and carcinogenic through integrating the viral DNA into the host genome. Then, it omits the early and late HPV genes known as E2, E4, E5, L1, and L2. Two early viral proteins have oncogenic potentials: E6 and E7 $(22,23)$. The high-risk HPVs (HR-HPVs) that are also carcinogens have a great ability to remain in human keratinocytes in vitro through a chronic status. These viruses penetrate the cervical epithelial cells and express the oncogenic protein E6 and E7, leading to the inactivation of host regulatory proteins p53 and then retinoblastoma protein $(\mathrm{RB})$. The viral antigen is a very specific type of antigen marking tumor cells. It is presented in viral-mediated carcinogenesis. Thus, the point that should be considered is that the best target to have an antitumor therapeutic goal is this antigen that is expressed just by the infected cells. This is somehow a way to block the autoimmunity cascade. Viral antigens can also act along with tumor-associated antigens in case of the dependence of oncogenes on expressing viral oncoproteins in infected cells. Scientists try to develop anticancer gene therapy because of the relationship between HPV infection and cervical cancer (24). When HPV starts to integrate into the host genome, the malignant transformation occurs. Hereby, E6 and E7 are expressed. Therefore, they have been targeted by several types of vaccines. It is proven that vaccines have a satisfactory result against these antigens in HPV-induced cervical dysplasia (25-27). They are applied in the clinical trial phase to treat cervical and head and neck cancers (28). The integration of the genome to the cell is necessary to induce cervical cancer. So persistent HPV infection is not the only or sufficient factor to this point (29). HPV 18 has a great power to integrate into the host genome leading to malignancy (3032). The fragile sites of chromosome have this integration that causes disruption to the open-reading frame of E2 and less commonly E1, E4 or E5 $(29,30)$. Tables 1 and 2 present complete data of the statistics as well as present screening methods, diagnostic methods, and available treatments of different types of HPV-related diseases.

\section{Molecular Diagnosis of HPV}

The molecular techniques are the main instrument to detect HPV DNA because of hard cultivation of HPV in culture systems. Although the E1 gene is used, the L1 and L2 late genes encode viral capsid proteins are used for HPV genotypes detection. The diagnostic techniques for detection and genotyping of HPV were classified as shown in Figure 2. All the commercially available tests are listed in Table 3. 


\begin{tabular}{|c|c|c|c|c|c|}
\hline Type of disease & Prevalence & $\begin{array}{l}\text { Incidence } \\
\text { (per year) }\end{array}$ & $\begin{array}{l}\text { In which age it } \\
\text { mostly occurs? }\end{array}$ & $\begin{array}{c}\text { Related } \\
\text { types }\end{array}$ & Mortality \\
\hline Cervical cancer & $\begin{array}{c}\text { The } 3^{\text {rd }} \text { most common cancer in } \\
\text { women (156) } \\
\text { From } 31.6 \% \text { in eastern Africa } \\
\text { to a low prevalence of } 6.2 \% \text { in } \\
\text { southeastern Asia (17) }\end{array}$ & 569,847 in $2018(156)$ & $\begin{array}{l}15 \text { to } 44 \text { year } \\
\text { (156) }\end{array}$ & $16,18(157)$ & $\begin{array}{c}311,365 \text { deaths in } 2018 \\
\text { (156) }\end{array}$ \\
\hline $\begin{array}{l}\text { Vulvar and } \\
\text { vaginal cancer }\end{array}$ & $\begin{array}{c}\text { Rare }(158,159) \\
5.6 \%, 4.4 \%(160)\end{array}$ & $\begin{array}{c}27000 \text { and } 13000 \text { new } \\
\text { cases in } 2008 \text { respectively } \\
(156)\end{array}$ & $\begin{array}{c}\text { Females aged } 45 \\
\text { to } 49 \text { years old } \\
\text { (161) }\end{array}$ & $16,18(162)$ & $\begin{array}{l}880 \text { and } 400 \text { deaths in } \\
2007 \text { respectively (162) }\end{array}$ \\
\hline Anal cancer & $\begin{array}{c}\text { Rare (156) } \\
1.5 \% \text { of GI cancers }(163) \text { and } \\
\text { more than } 10 \% \text { in HPV positive } \\
\text { patients (164) }\end{array}$ & 27000 new cases (165) & $\begin{array}{l}\text { 65-69 years old } \\
\text { (166) }\end{array}$ & $16,18(167)$ & $\begin{array}{c}1 \text { - and } 5 \text {-year } \\
\text { mortality rates of } 40 \% \\
\text { and } 80 \% \text {, respectively } \\
(163)\end{array}$ \\
\hline $\begin{array}{l}\text { Esophageal } \\
\text { cancer }\end{array}$ & $\begin{array}{c}\text { The } 8^{\text {th }} \text { most common cancer } \\
(168) \\
11.7 \%-38.9 \%(169,170)\end{array}$ & 500000 new cases (168) & $\begin{array}{l}\text { Mean age } 65 \\
\text { years old (171) }\end{array}$ & $16,57(172)$ & $\begin{array}{l}406000 \text { deaths each } \\
\text { year }(168)\end{array}$ \\
\hline $\begin{array}{l}\text { Colorectal } \\
\text { cancer }\end{array}$ & $\begin{array}{l}\text { The third most common in men } \\
\text { and } 2 \mathrm{~d} \text { most common in wom- } \\
\text { en (173) } \\
\text { For prevalence rate Data not } \\
\text { found }\end{array}$ & $\begin{array}{c}141,270 \text { new cases in } 2016 \\
\text { (166) }\end{array}$ & $\begin{array}{l}\text { 65-79 years old } \\
\text { (174) }\end{array}$ & $\begin{array}{c}16 \\
(175,176)\end{array}$ & $\begin{array}{c}52,286 \text { deaths each year } \\
\text { (166) }\end{array}$ \\
\hline Prostate cancer & $\begin{array}{l}\text { The most common cancer in } \\
\text { men }(177) \\
15 \%(178)\end{array}$ & 160000 new cases (177) & $\begin{array}{l}72-74 \text { years old } \\
\text { (179) }\end{array}$ & $16(180)$ & $\begin{array}{c}11,710 \text { each year in the } \\
\text { US between 1988-92 } \\
\text { (181) }\end{array}$ \\
\hline $\begin{array}{l}\text { Urothelial } \\
\text { cancer }\end{array}$ & $\begin{array}{c}\text { The } 4^{\text {th }} \text { most common cancer } \\
(182) \\
3 \%-50 \%(183-185)\end{array}$ & 150,350 new cases $(182)$ & $\begin{array}{l}\geq 65 \text { years old } \\
\quad(186)\end{array}$ & $16,18(187)$ & $\begin{array}{l}132,432 \text { worldwide in } \\
2000(186)\end{array}$ \\
\hline $\begin{array}{l}\text { Testicular } \\
\text { cancer }\end{array}$ & $\begin{array}{c}1 \% \text { of all male cancers }(188) \\
0.066 \%(166)\end{array}$ & 14.9 per $100,000(166)$ & $20-39(166)$ & $\begin{array}{c}16(189- \\
191)\end{array}$ & $2 \%(188)$ \\
\hline Renal cancer & $\begin{array}{c}\text { The } 6^{\text {th }} \text { most common cancer in } \\
\text { men and the } 10^{\text {th }} \text { most common } \\
\text { cancer in women }(160) \\
0.3 \%(166)\end{array}$ & $\begin{array}{l}22.8 \text { per } 100,000 \text { men and } \\
11.6 \text { per } 100,000 \text { women } \\
\text { each year }(166)\end{array}$ & $\begin{array}{l}\text { 65-84 years old } \\
\text { (166) }\end{array}$ & $\begin{array}{l}\text { Data not } \\
\text { found }\end{array}$ & $\begin{array}{c}\text { About } 9,000 \text { men and } \\
5,000 \text { women each year } \\
\text { (166) }\end{array}$ \\
\hline Penile cancer & $\begin{array}{c}\text { Rare (156) } \\
6 \%(192)\end{array}$ & 22000 new cases (156) & $\begin{array}{l}50-70 \text { years old } \\
\text { (156) }\end{array}$ & $\begin{array}{c}16,18 \\
31,33(193)\end{array}$ & $30 \%(194)$ \\
\hline $\begin{array}{l}\text { Head and neck } \\
\text { squamous cell } \\
\text { carcinoma }\end{array}$ & $\begin{array}{c}\text { Less than } 5 \% \text { of all cancers } \\
(195) \\
6.9 \%(196)\end{array}$ & $\begin{array}{c}644,000 \text { new cases each } \\
\text { year }(195)\end{array}$ & $\begin{array}{c}\leq 45 \text { years old } \\
\quad(195)\end{array}$ & $16(197)$ & $2.2 \%(195)$ \\
\hline $\begin{array}{l}\text { Cutaneous } \\
\text { squamous cell } \\
\text { carcinoma }\end{array}$ & $\begin{array}{c}\text { The } 2 \mathrm{~d} \text { most common form of } \\
\text { skin cancers (198) } \\
9-14 \% \text { in } \\
\text { men and } 4-9 \% \text { in women (195) }\end{array}$ & $\begin{array}{l}700,000 \text { new cases each } \\
\text { year in US (199) }\end{array}$ & $\begin{array}{l}\text { In ages }>35 \text { years } \\
\text { old }(200)\end{array}$ & $\begin{array}{l}\beta-H P V \text { such } \\
\text { as } 5 \text { and } 8 \\
(200,2: 01)\end{array}$ & $2.1 \%(198)$ \\
\hline Warts & $\begin{array}{c}\text { One of the common sexually } \\
\text { transmitted } \\
\text { Peak prevalence of } 53.8 \% \\
(202)\end{array}$ & $\begin{array}{c}14,100,000 \text { new cases each } \\
\text { year }(166)\end{array}$ & $\begin{array}{c}\text { Peak } \\
\text { prevalence 20- to } \\
24(202)\end{array}$ & $\begin{array}{c}6,11,42 \\
43,44(114)\end{array}$ & $\begin{array}{l}\text { Significant source of } \\
\text { morbidity and mortality } \\
\text { worldwide (203). } \\
\text { (Data about the exact } \\
\text { rate was not found) }\end{array}$ \\
\hline
\end{tabular}

\section{Nucleic Acid Detection-based Methods}

\subsection{Nucleic Acid Amplification-based Methods}

These methods are generally based on the polymerase chain reaction that is used for amplifying, detecting, and typing the HPV DNA by the use of degenerate primers MY09/MY11 or PGMY09/11, GP5+/6+ and SPF10 to amplify the viral capsid L1 gene (33-35).

1. The Conventional PCR-based Methods: The conven- tional PCR based methods are single or double nestedPCR $(36,37)$ multiplex-PCR (38) and nested-PCR-RFLP assay (34). Then, the PCR product is amplified by targeting a type-specific DNA sequence or treatment with restriction enzyme to determine the specific sequence existing in the sample related to a specific type of HPV (39, 40) 
2. The PCR Following by Hybridization-based Methods: The methods-based amplification of target DNA following hybridization include traditional PCR in situ hybridization (PISH), microplate colorimetric hybridization assay (MCHA), the linear array for HPV genotyping, and the reverse line hybridization. The PISH technique is the typical PCR performed on the slide of intact paraffinembedded tissue, and then hybridized with specific DNA probes $(41,42)$. The MCHA is a method based on PCR followed by colorimetric hybridization to type-specific probes on microplates (43). In the reverse line blot assays and the linear array HPV genotyping, after the amplifying step, the sequences are fixed on a membrane strip and detected by type-specific probe $(39,44)$.

3. PCR-based Fluorescent-based Array: Microarraybased HPV genotyping assays employ the PCR to amplificate the viral genome fragment and then hybridize with several HPV-specific oligonucleotide probes attached on

Table 2. Pathogenesis, screening methods, diagnostic methods, treatment, and some useful information in brief. Abbreviations: ESCC, esophageal squamous cell cancer; EAC, esophageal adenocarcinoma; GEJAC, gastroesophageal junction adenocarcinoma; BC.G: Bacillus Calmette-Guerin; CT scan, computed tomography scan; MRI, magnetic resonance imaging.

$\begin{array}{llll}\text { Type of Disease } & \text { Pathogenesis } & \text { Screening \& Diagnostic Methods } & \text { Treatment }\end{array}$

\begin{tabular}{|c|c|c|c|c|}
\hline Cervix & $\begin{array}{l}\text { Cervical intraepi- } \\
\text { thelial neoplasia } \\
\text { exists due to } \\
\text { chronic infection } \\
\text { that can lead to } \\
\text { cervical cancer } \\
\quad(204)\end{array}$ & $\begin{array}{c}\text { Pap smear (149) } \\
\text { Colposcopy, cervical biopsy } \\
\text { (149), avoid unnecessary exci- } \\
\text { sions (205) }\end{array}$ & $\begin{array}{l}\text { Ursodeoxycholic acid (UDCA), chie- } \\
\text { nodeoxycholic acid (CDCA), synthetic } \\
\text { CDCA derivatives like HS-1199 and } \\
\text { HS-1200 and the system of the chollic } \\
\text { acid-functionalized star-shaped PLGA- } \\
\text { b- TPGS (CA-PLGA-b-TPGS), poly- } \\
\text { meric nanoparticles control delivery of } \\
\text { the drug, such as Docetaxel (149) }\end{array}$ & $\begin{array}{c}\text { Progression of precursor } \\
\text { lesions for cervical cancer } \\
\text { takes more than } 10 \text { years } \\
(160,206,207)\end{array}$ \\
\hline $\begin{array}{l}\text { Vulvar and } \\
\text { vaginal }\end{array}$ & $\begin{array}{l}\text { Vulvar and vagi- } \\
\text { nal intraepithelial } \\
\text { neoplasia (VIN } \\
\text { and VaIN) (208, } \\
\text { 209) }\end{array}$ & $\begin{array}{l}\text { No screening methods are availa- } \\
\text { ble (4) } \\
\text { Direct visual examination, biopsy } \\
\text { and histopathological examination } \\
\text { (210) }\end{array}$ & $\begin{array}{l}\text { Surgery, external or internal radiation } \\
\text { therapy, and systemic or regional } \\
\text { chemotherapy }(211)\end{array}$ & $\begin{array}{l}\text { The current treatment } \\
\text { strategies, unfortunately, } \\
\text { are not successful. The } \\
\text { relapse rate is high (158) }\end{array}$ \\
\hline Anal & $\begin{array}{l}\text { Strongly links to a } \\
\text { complex inflam- } \\
\text { matory process } \\
\text { leading to anal } \\
\text { cancers of squa- } \\
\text { mous cell origin } \\
\quad(167)\end{array}$ & $\begin{array}{l}\text { Anal Papanicolaou smears (pap) } \\
\text { and Southern blotting (212) } \\
\text { High-resolution anoscopy (HRA) } \\
\text { (212) }\end{array}$ & $\begin{array}{l}\text { An organized team to plan chemother- } \\
\text { apy, radiation therapy and surgery ( } 5)\end{array}$ & $\begin{array}{c}\text { It has a ratio of female to } \\
\text { male being as high as } 5: 1 \\
(165) . \text { HPV was positive in } \\
83 \%-95 \% \text { of patients } \\
\text { (213). HPV is the reason } \\
\text { for } 90 \% \text { of SCCA }(214 \text {, } \\
215)\end{array}$ \\
\hline $\begin{array}{l}\text { Esophageal } \\
\text { cancer }\end{array}$ & $\begin{array}{l}\text { Chronic infection } \\
\text { leads to ESCC } \\
\text { (216) }\end{array}$ & $\begin{array}{l}\text { In high incidence area regular } \\
\text { endoscopy (171) } \\
\text { Endoscopy and biopsy (217) }\end{array}$ & $\begin{array}{c}\text { Chemotherapy, radiation therapy and } \\
\text { surgery }(217)\end{array}$ & $\begin{array}{l}\text { A significant relation be- } \\
\text { tween HPV and ESCC but } \\
\text { not with EAC and GEJAC. } \\
\text { Identification of HPV in } \\
\text { this malignancy can be } \\
\text { helpful for better response } \\
\text { and outcome (216) }\end{array}$ \\
\hline $\begin{array}{l}\text { Colorectal } \\
\text { cancer }\end{array}$ & $\begin{array}{l}\text { Chronic infection } \\
\text { leads to mutations } \\
\text { in glandular cells } \\
\text { of the colorectal } \\
\text { mucosa of colon } \\
\text { and rectum (218) }\end{array}$ & $\begin{array}{l}\text { Fecal occult blood test and colon- } \\
\text { oscopy (219) } \\
\text { Colonoscopy and biopsy (220) }\end{array}$ & $\begin{array}{c}\text { Chemotherapy, radiation therapy and } \\
\text { surgery }(220)\end{array}$ & $\begin{array}{l}\text { Identification of HPV in } \\
\text { this malignancy can be } \\
\text { helpful for better response } \\
\text { and outcome (216) }\end{array}$ \\
\hline Prostate cancer & Still unclear (150) & $\begin{array}{l}\text { Prostate-specific antigen (PSA) } \\
\qquad(179) \\
\text { Tissue biopsy (217) }\end{array}$ & $\begin{array}{l}\text { Chemotherapy, radiotherapy and sur- } \\
\text { gery and androgen deprivation therapy } \\
(217)\end{array}$ & $\begin{array}{l}\text { It is important to keep } \\
\text { HPV infection in mind } \\
\text { when encounters with } \\
\text { unusual disease manifesta- } \\
\text { tions of the urogenital tract } \\
\qquad(221)\end{array}$ \\
\hline $\begin{array}{l}\text { Urothelial } \\
\text { cancer }\end{array}$ & Still unclear (222) & $\begin{array}{l}\text { No recommended screening } \\
\text { method (223) } \\
\text { Applying CT urography or MRI } \\
\text { for upper urinary tract evaluation } \\
\text { and cystoscopy for lower urinary } \\
\text { tract evaluation }(224)\end{array}$ & $\begin{array}{l}\text { Intravesical chemotherapy or intravesi- } \\
\text { cal BCG (224) }\end{array}$ & $\begin{array}{l}\text { Urothelial cancer is an } \\
\text { overarching term that } \\
\text { describes a number of } \\
\text { tumors that arise from the } \\
\text { urothelial lining of the } \\
\text { bladder, renal pelvis, ure- } \\
\text { ters, and urethra (225) }\end{array}$ \\
\hline $\begin{array}{l}\text { Testicular can- } \\
\text { cer }\end{array}$ & $\begin{array}{l}\text { It leads not direct- } \\
\text { ly to testicular } \\
\text { cancer but can } \\
\text { provide a status of } \\
\text { higher vulnerabil- } \\
\text { ity induced by the } \\
\text { tumor }(226)\end{array}$ & $\begin{array}{l}\text { No recommended screening } \\
\text { method (227) } \\
\text { Transscrotal ultrasonography } \\
\text { (228) }\end{array}$ & $\begin{array}{l}\text { Orchiectomy, chemotherapy and radio- } \\
\text { therapy (229) }\end{array}$ & No Additional information \\
\hline
\end{tabular}


Table 2. Ctd

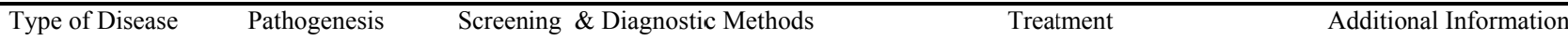

\begin{tabular}{|c|c|c|c|c|}
\hline Renal cancer & $\begin{array}{l}\text { Still unclear }(230- \\
232)\end{array}$ & $\begin{array}{l}\text { No recommended screening } \\
\text { method (182) }\end{array}$ & $\begin{array}{l}\text { Surgery, chemotherapy, immunothera- } \\
\text { py, or targeted therapy (182) }\end{array}$ & No Additional information \\
\hline \multirow[b]{2}{*}{ Penile cancer } & \multirow[b]{2}{*}{$\begin{array}{l}\text { Penile intraepithe- } \\
\text { lial neoplasia } \\
\text { (PIN) (234) }\end{array}$} & $\begin{array}{l}\text { Renal CT scan with and without } \\
\text { contrast or MRI with and without } \\
\text { gadolinium enhancement (233) }\end{array}$ & & \\
\hline & & $\begin{array}{l}\text { Data not found for screening } \\
\text { methods } \\
\text { No imagining technique can ex- } \\
\text { actly detect micrometastatic } \\
\text { lymph nodes. So, invasive ingui- } \\
\text { nal lymph node diagnosis is rec- } \\
\text { ommended for all tumor stages } \\
\text { from pT1G2 (235) }\end{array}$ & $\begin{array}{l}\text { Surgical methods (circumcision, wide } \\
\text { local excision, and glans resurfacing), } \\
\text { T-cell immune checkpoint inhibitors, } \\
\text { and HPV genome targeting strategies } \\
(236,237)\end{array}$ & $\begin{array}{l}\text { Penile SCC has four sub- } \\
\text { groups: warty, basaloid, } \\
\text { keratinizing, and verru- } \\
\text { cous. Only the first two } \\
\text { groups (warty and } \\
\text { basaloid) are related to } \\
\text { HPV }(238,239)\end{array}$ \\
\hline \multirow[t]{2}{*}{$\begin{array}{l}\text { Head and neck } \\
\text { squamous cell } \\
\text { carcinoma }\end{array}$} & \multirow[t]{2}{*}{$\begin{array}{l}\text { Still unclear }(240- \\
\text { 242) }\end{array}$} & $\begin{array}{l}\text { P16 IHC, FISH, HPV genome } \\
\text { detection in biopsy specimens } \\
\text { (243) }\end{array}$ & $\begin{array}{l}\text { EGFR TKI and low-dose radiation, } \\
\text { trans-oral robotic surgery, many reduc- } \\
\text { tion surgeries and post-operative adju- } \\
\text { vant therapies based on pathologic } \\
\text { staging (244) }\end{array}$ & $\begin{array}{l}\text { HPV-positive OPSCCs } \\
\text { have a better therapeutic } \\
\text { response and prognosis } \\
(240-242)\end{array}$ \\
\hline & & $\begin{array}{l}\text { Endoscopy (nasopharyngolaryn- } \\
\text { goscopy, } \\
\text { esophagoscopy, and bronchosco- } \\
\text { py, } \\
\text { as appropriate) and biopsies (195) }\end{array}$ & & \\
\hline $\begin{array}{l}\text { Cutaneous } \\
\text { squamous cell } \\
\text { carcinoma } \\
(\mathrm{CSCC})\end{array}$ & $\begin{array}{l}\text { CSCC is mostly } \\
\text { seen in patients } \\
\text { with epidermodys- } \\
\text { plasia verruciform- } \\
\text { is }(\mathrm{EV}) \text {. EV is an } \\
\text { autosomal reces- } \\
\text { sive genodermato- } \\
\text { sis existed through } \\
\text { mutations in EV- } \\
\text { ER } 1 \text { and EVER } 2 \\
\text { genes }(200,201)\end{array}$ & $\begin{array}{c}\text { A total-body examination of the } \\
\text { skin is the only screening test } \\
\text { available (195) }\end{array}$ & $\begin{array}{l}\text { Surgical excision, cryotherapy, curet- } \\
\text { tage, electrodesiccation, topical treat- } \\
\text { ments (e.g imiquimod, 5-FU, ingenol } \\
\text { mebutate, diclofenac, and retinoids) } \\
\text { and radiation therapy }(245)\end{array}$ & $\begin{array}{l}\text { Although most of CSCC } \\
\text { have an excellent progno- } \\
\text { sis, some of them are sus- } \\
\text { ceptible to have poor out- } \\
\text { comes (198) }\end{array}$ \\
\hline \multirow[t]{2}{*}{$\begin{array}{l}\text { Warts (Condy- } \\
\text { loma acumin- } \\
\text { ate) }\end{array}$} & $\begin{array}{l}\text { Available in the } \\
\text { text. }\end{array}$ & $\begin{array}{c}\text { Regular } \\
\text { physical examination, cytolo- } \\
\text { gy/viral detection }(246)\end{array}$ & $\begin{array}{l}\text { Topical and systemic. Trichloroacetic } \\
\text { acid (TCA) is the best }(124,125)\end{array}$ & Available In the text. \\
\hline & & $\begin{array}{l}\text { Histologic examination of biopsy } \\
\text { specimens (118) }\end{array}$ & & \\
\hline
\end{tabular}

the surface of an insoluble supporter like bead or DNA chip (45-53). The suspension array genotyping assays use bead-based technology, which is based on the use of polystyrene beads dyed with 2 spectrally distinct fluorophores (red and infrared), and each bead set is coupled with a specific oligonucleotide probe for $1 \mathrm{HPV}$ type. The HPV sequences are amplified, denatured, and hybridized with the bead-bound probes. Then, hybridized biotinylated amplicons that are labeled by using phycoerythrin and streptavidin are served as a reporter fluorophore. The bead sets are then read and analyzed on a Luminex analyzer (54$60)$.

4. The Real-time PCR-based HPV Genotyping-based Methods: The real-time PCR is reliable and sensitive, with high accuracy and validity in HPV-DNA detection and genotyping. Also, the viral load quantification and the capability of multisample qualification with different fluorochromes is the advantage. In this method the fluorescent probes in cooperation with PCR primers allow for quanti- fication of the viral genome and are presented in a sample as the name "viral load" $(61,62)(63-65)$. The cobas 4800 HPV test uses multiplex real-time PCR and nucleic acid hybridization with 4 different fluorescent reporter probes that concurrently detects the $\mathrm{L} 1$ gene $(64,66)$.

5. HPV E6/E7 mRNA-basedl Screening Assays: The detection of viral mRNA is based on transcription-mediated amplification of full-length E6/E7 transcripts accomplished by target capture. Reverse-transcriptase-PCR incorporates is a RT step following real-time quantitative PCR. The oncoproteins E6 and E7 are the most relevant transcripts for diagnostic and carcinogenesis follow-up. $(67,68)$. The main techniques used to detect mRNA for E6/E7 oncogenes are 3 commercial assays shown in Table $3(45,68-71)$.

\subsection{Signal Amplification}

Signal amplification describes methods-based probe molecule, which are hybridized to the target nucleic acid 


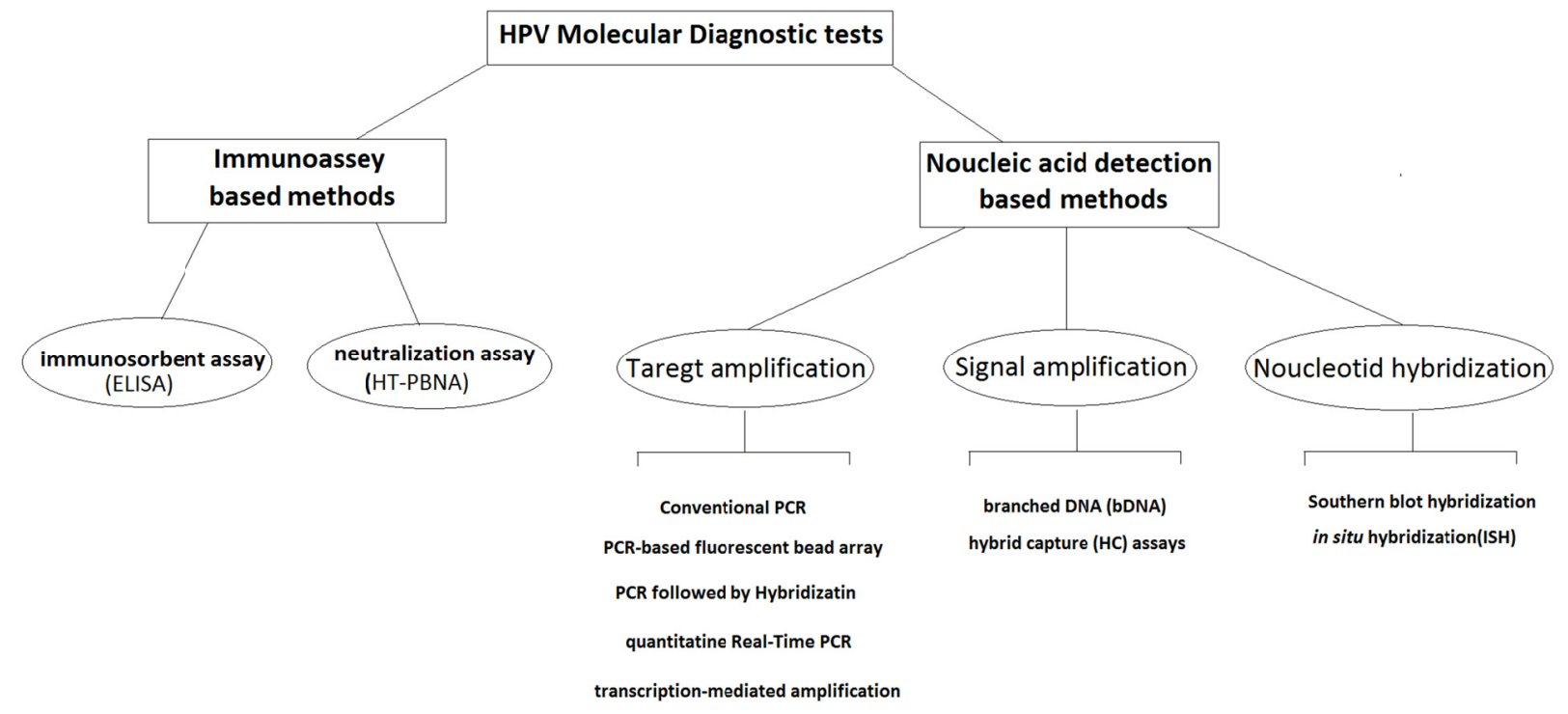

Fig. 2. The schematic classification of diagnostic techniques for detection and genotyping of HPV

sequence and generate the signal related to amplification rate (72). Signal amplification technologies include branched DNA (bDNA) and hybrid capture (HC) assays $(73,74)$. The hybrid capture method is the most widelyused signal amplification method that briefly samples DNA hybridized with the cocktail of RNA probes. The RNA-DNA hybrids indicate the presence of HPV DNA and subsequently it is revealed by the nonradioactive signal-amplification method to aid detection (73-76). The Digene HCII technology served as the second version of hybrid capture (77). The bDNA assay directly measures nucleic acid molecules and is based on binding the subset of "target probes" bound to specific nucleotide sequences (exist in the sample) as in situ hybridization (bDNA ISH) $(72,74)$. The Cervista HPV test is a signal amplification method that uses 2 types of isothermal reactions, which is briefly based on the enzymatic cleaves the FRET oligonucleotides between the fluorophore and quencher molecule, resulting in the production of a fluorescence signal (39, 42, 74).

\subsection{Noucleotid Hybridization-based Methods}

The nonamplified HPV techniques include in southern/dot blot hybridization, and in situ hybridization (ISH). This method is generally time-consuming, requires more skill, necessary equipments, and is not as sensitive and reliable as the molecular methods. briefly, in HPV DNA detection by southern blot, the sample extracted DNA is digested by restriction enzymes and then runs in agarose gel electrophoresis to separate the digested DNA based on the size, and then is transferred to a nitrocellulose or nylon membrane and finally hybridized with cloned HPV genomic probes labeled with isotopic $\left(\mathrm{P}^{32}\right)$ or nonisotopic (digoxigenin) techniques. The detection procedure in ISH occurs right on the fixed nuclei of infected cells (in situ) and hybridization reaction is evaluated microscopically $(78,79)$ In comparison with $\mathrm{P}^{\prime} \mathrm{CR}$, the blot hybridizationbased method has higher specificity but is less sensitive $(42,80,81)$.

\section{Immune-biochemical-basied Methods}

1. HPV serology - ELISA assay: The serological tests to determine the HPV virus are performed based on VLPs (virus-like particles)(82-84), and the sensitivity is about $50 \%(85)$. Three forms of Elisa method include (1) Direct assays binding to HPV VLPs on the microplate; (2) indirect assays binding to HPV VLPs to the microplate via anti-VLP antibodies; and (3) Competitive assay by which the antigen is coated on fluorescent beads (Luminex-based assays) exposed to the sample $(54,58,86)$.

2. HPV Neutralization Assay: High-throughput pseudovirion-based neutralization assay (HT-PBNA) with excellent repeatability and run-to-run reproducibility was developed for HPVs (86). HPV neutralization assays rely on neutralization of one of the following items: authentic virions, pseudotyped virions that are capsids carrying a reporter gene on their surface, and pseudovirions (PsVs) that have encapsidated reporter genes to assess anti-VLP conformational antibodies neutralizing activity. The neutralization assays are the gold standard to assess the protective potential of antibodies induced by HPVs vaccines in experimental systems (87-89).

\section{The Potential Biomarkers for HPV Detection}

The biomarkers related to high-risk HPV infection can help to enhance the sensitivity of cervical cytology screening, reduce false-negative dliagnoses, monitoring and prognosis of related diseases. 


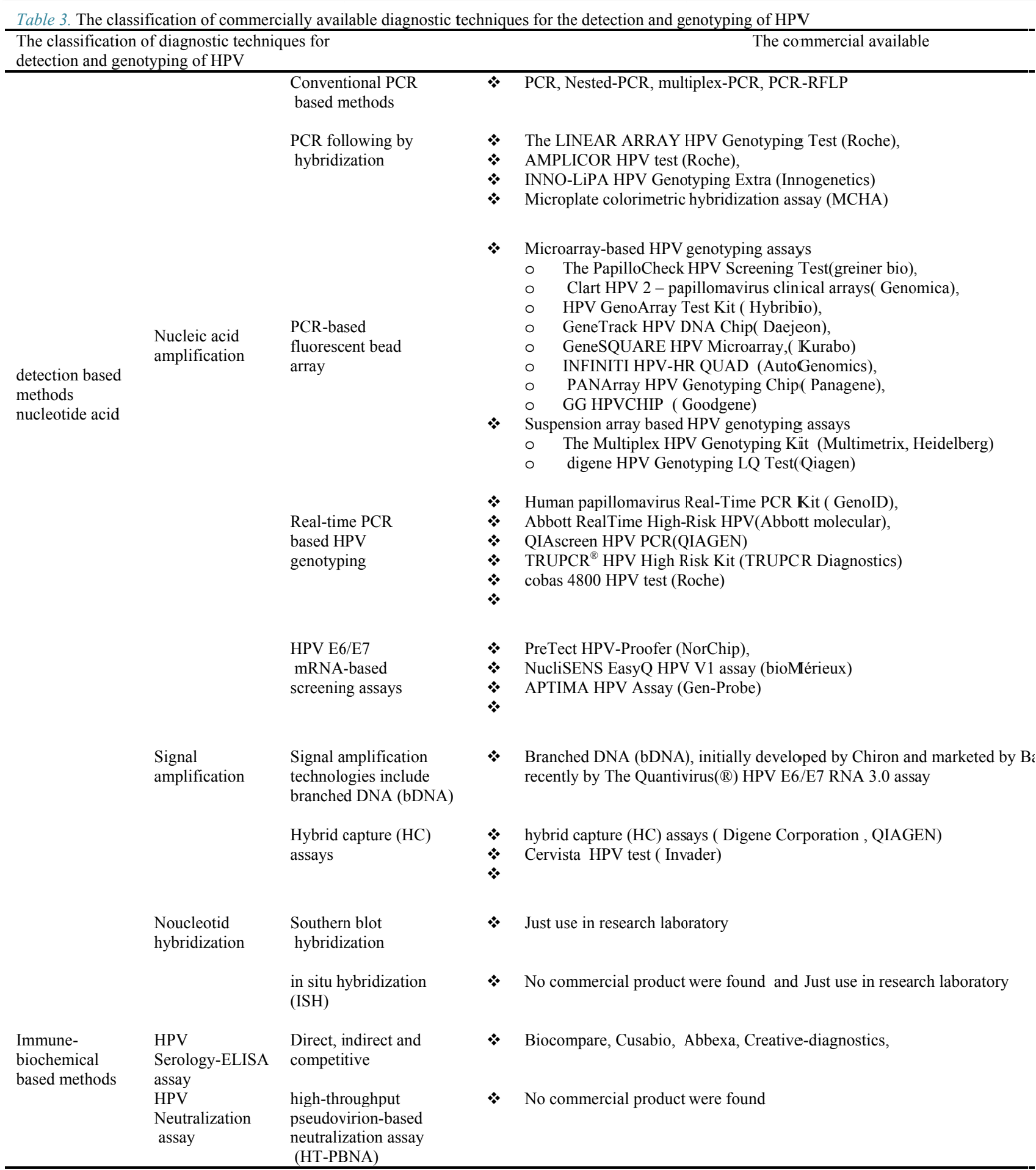

The potential biomarker in cervical cancer includes in p16INK4a, Ki-67 that are the target of E6 and E7 oncoprotein (90-93). There are many molecular targets of E6 and E7, such as Wnt/ $\beta$-catenin/Notch (94, 95), $\mathrm{PI3K} / \mathrm{AKT} / \mathrm{mTOR}$ pathway (96), P53, and $\mathrm{PRb}(97,98)$. The molecular targets of HPV E5 oncoprotein are the cell surface receptors like EGFR (99, 100), p21Wafl/Sdil/Cip(101), p27KIP1(102), COX-2, VEGF, and Cav-1(102). Besides, the host microRNAs have been affected by HPV proteins E5, E6, and E7. Increased expression of miR-16, miR-25, miR-92a, and miR-378, and decreased expression of miR-22, miR-15a, miR-15b, miR21and miR29a miR-16, miR-27a, miR-29a, and miR-100 are attributed to viral oncoprotein E6 or E7 (103-108). The miRNA-944(109) and miRNA-155(110) overexpression as well as downregulation of miRNA-375 (111) can potentially be served as a biomarker for cervical cancer follow-up. Dysregulation of miR-375/AEG-1 Axis by HPV high-risk 16 and 18 E6/E7 promotes cellular proliferation, migration, and invasion in cervical cancer (112). 


\section{Warts}

Condyloma acuminate (CA) or wart is one of the most common sexually transmitted diseases in the world (15). The incubation period is 3 weeks to 8 months, and the clinical manifestation takes 2 to 3 months (113). The viruses producing genital warts are usually the low-risk types of HPV: 6, 11, 42, 43, and 44. types 6 and 11 are detected in $90 \%$ of cases. A study in 2009 has reported that $31 \%$ of patients with CA have a high-risk HPV as coinfection (114). A cohort study in 2019 reprted that the high-risk HPV genotypes could also be associated with warts. Particularly, a large number of patients with CIN23 and milder lesions with CIN1 were carriers of a virus of a HPV-HR genotype (115). Typically, CA is mostly discrete, skin-colored, brown or whitish, pedunculated ,or broad-based with a variation in size from 1 millimeter to several centimeters (116). They are usually found on the external genitalia, perineum, perianal area, and oral cavity (117). Warts are most often diagnosed through their clinical appearance. Laboratory tests for the presence of HPV are not recommended for the diagnosis of CA. Histologic examination of biopsy specimens can be performed to rule out intraepithelial or invasive squamous cell carcinomas SCCs, which can coexist with or appear similar to anogenital warts (118). Their feature in histologic evaluation involves epidermal hyperplasia, parakeratosis, koilocytosis, and papillomatosis (119). Unfortunately, there is not any definite antiviral therapy to treat anogenital warts. Recurrence rate is high $(25 \%-65 \%)$, which is may be due to the widespread infection and subclinical lesions (120). Also, most of the treatments are time-consuming and uncomfortable (121). Since there are no specific therapy options, the therapist should consider many points for the treatment such as the number, size, morphology, anatomic location, patient preference and side effects (122). The available therapies are effective for $60 \%$ to $90 \%$ of nonimmunosuppressed patients $(121,123)$. About trichloroacetic acid (TCA), it is investigated that $71 \%$ to $79 \%$ of cases regressed from high grade squamous intraepithelial lesion (HSIL) to low-grade squamous intraepithelial lesion (LSIL) or complete resolution when using TCA (124). The current treatments used for warts are as below:

1. Topical, destructive, surgical: podophyllotoxin and podophyllin, imiquimod, sinecatechins, intralesional immunotherapy with skin test antigens, cidofovir, 5fluorouracil (5-FU), TCA, cryotherapy, potassium hydroxide, surgical excision, laser therapy, and photodynamic therapy

2. Systemic: interferon, isotretinoin (125).

\section{The Risk of Infertility}

Infertility means the inability of a couple to have a gestational process after 1 year of unprotected sex. Approximately $10 \%$ to $20 \%$ of couples at the reproductive age are suffering from infertility. Also, 50\% of the reasons for infertility among couples relate to male factors, such as sexual dysfunction, congenital dysplasia, endocrine disorders, varicocele, immune factors, and sexually transmitted infections (126-128). It is established that there is a correlation between cervical disease and pregnancy complica- tions (129). Nonetheless, we do not have any definite evidence recognizing the influence of HPV infection on pregnancy, such as preeclampsia, preterm labor, or fetal growth restriction (130). In men, the story is as in women. The literature supporting a link between HPV and infertility is still controversial (131). Seminal HPV infection is common worldwide, which may be correlated with the risk of male infertility through affecting sperm abnormalities, such as low sperm count and motility. Some studies have reported that HPV 16 and 52 in men and HPV 58 in women are the most common types of HPVs leading to infertility $(24,132)$.

\section{Vaccination}

There is no definite therapy for HPV infection. Sometimes it is eliminated on its own. Some scientists believe that it cannot be cleared completely and may only switch to undetectable levels (133). We have several types of therapeutic vaccines evaluated in preclinical and clinical trials: live vector, protein or peptide, nucleic acid, and cell-based vaccines (134). However, 3 HPV vaccines are currently available in the vacination program: cervarix (bivalent vaccine for HPV 16, 18), gardasil (quadrivalent vaccine for HPV $6,11,16,18)$, and nonavalent vaccine (for HPV 6, 11, 16, 18, 31, 33, 45, 52, 58). These vaccines can target between 2 and 7 oncogenic HPV serotypes (135). They promise, in the long-term (30-50 years), to reduce the incidence of disease associated with HPV vaccine types (136). Some studies have proved that HPV vaccination is a secure and efficient method to prevent cancer $(137,138)$. Steben et al in 2018 evaluated 10 years of clinical experience in Canada. The results indicated that the prevalence of HPV types 16, 18, 6, and 11 was lower in qHPV-vaccinated than unvaccinated individuals $(1.5 \%$ vs $11 \%$ ). The risk of anogenital warts incidence had a decrease by up to about $45 \%$ in vaccinated population in cohort studies and the incidence of cervical intraepithelial neoplastic had a significant decrease by up to $86 \%$. These researchers concluded that the programs of HPV vaccination constitute an effective and useful public health initiative (139). Unfortunately, there is limited vaccination coverage of large populations in the world. Therefore, a gross unvaccinated population remains at a high risk of HPVassociated disease (14). Additionally, some researches have demonstrated that current vaccines will not be useful for preventing all types of HPV-related cancers (140). Also, the HPV subtype distribution in cervical cancer varies throughout the world $(141,142)$. Japanese scientists in 2019 reported a significant number of adolescent girls complaining of unusual symptoms after HPV vaccination. The vast majority of them had psychiatric illness in the absence of any pathologic findings in radiological images or laboratory tests. So the recommendation of vaccination was withdrawn by the Japanese Ministry of Public Health (143). At present, the vaccination program is implemented in Argentina, Australia, Austria, Belgium, Bhutan, Brazil, Brunei, Darussalam, Canada, Colombia, Cook Islands, Czech Republic (the), Denmark, Fiji, France, Germany, Greece, Iceland, Ireland, Israell, Italy, Japan, Kiribati, Latvia, Lesotho, Luxembourg, Malaysia, Marshall Islands 
(the), Mexico, Micronesia, Netherlands, New Zealand, Norway, Palau, Panama, Paraguay, Portugal, Rwanda, San Marino, Singapore, Slovenia, Spain, Sweden, Switzerland, United Kingdom of Great Britain, the former Yugoslav Republic of Macedonia, Uganda, and Northern Ireland, Trinidad and Tobago, United States of America (the), and Uruguay (144).

\section{Discussion}

HPV transmission risk is increased among multipartners. It can originate from a genital area and extend to other parts like the anus region. Neonates can be infected by their mothers during pregnancy or the delivery period through vertical and perinatal transmission (145). The transmitted couples are sexually more active with a history of not using condoms regularly. It shows that condoms can be effective, along with the prophylactic vaccines. Despite the $3 \%$ of transmitting couples, more than $50 \%$ of nontransmitting couples presented that during the previous 4 months they used condoms in $100 \%$ of intercourses (146). So condoms can be used to protect against HPV but since they do not cover every possible HPV-infected area of the body, they cannot offer full protection (147). According to a cohort study done by Hernandez et al, genital transmission from women to men occurs more frequently than from men to women. The primary source of transmission to the cervix is the penis. The cervix and urethra are the primary sources of infection to male genitals. Sexual transmission implicates also the scrotum, the anus of women, and the hands of both genders. In heterosexual transmission the anus of women plays an important role as a major source and target. It is found that HPV transmission does not definitely influence the target organs because it depends on the tissue or genotype differences or both (146).

Epidemiologist research finds that HR-HPVs play an important role in cervical cancer and bacterial vaginosis $(148,149)$. After the integration of the genome, E6 oncogene is expressed. Many cells have changed by the E6 protein, leading to inhibition of apoptosis and increased telomerase function. This is why E6 protein can prolong cellular lifespan. It functions as a transcriptional activator accompanied by this prolonged lifespan and transforms cells (150). HR-HPV E7 allows the cell to increase its transforming activities. Therefore, human keratinocytes are immortalized because they interact with factors that regulate cell growth (151). Based on the our results, the expression of E6 and E7 can be blocked by E2. After disrupting, it enables uninhibited E6 and E7 oncoprotein activity (31). The differences between low-risk and high-risk HPVs in producing warts or cancers is mainly in E6 and E7 function. In low-risk HPVs, E6/E7 expression stimulates cell cycle entry in the upper epithelial layers (differentiating cells), allowing genome amplification in both low and high-risk HPVs. Also, basal cell proliferation may still be stimulated by growth factors, but not E6/E7. There is little or no expression of E6/E7. About high-risk HPVs, E6/E7 expression stimulates additional cell cycle entry and cell proliferation in the basal and parabasal epithelial layers leading to neoplasia. E6/E7 inhibit immune response to tolerate viral gene expression (152). HPV vaccines provide a promising primary approach to prevent malignancies. Because HPV acquisition generally occurs soon after first sexual activity, vaccine effectiveness will be lower in older age groups because of prior infections. Evidence suggests that although HPV vaccination is safe for adults aged 27 to 45 years, population benefit would be minimal; nevertheless, some adults who are not adequately vaccinated might be at risk for new HPV infection and might benefit from vaccination in this age range. Vaccination is routinely recommended at age 11 or 12 years; it can be given starting at age 9 years. Although catch-up HPV vaccination is recommended for all persons through age 26 years who are not adequately vaccinated, it is not recommended for all adults aged $>26$ years. Instead, shared clinical decision-making regarding HPV vaccination is recommended for some: adults aged 27 to 45 years who are not adequately vaccinated. HPV vaccines are not licensed to be used in adults aged $>45$ years (153).

\section{Strengths}

This was a comprehensive review study involving 353 valid publications evaluating all important aspects of HPVs and their related cancers. Most of the studies have evaluated only 1 or 2 types of cancers correlated with HPVs. The need for easily accessible comprehensive data in this field seemed to be necessary. Thus, we tried to provide such data for clinicians and laboratory specialists working on HPV infection.

\section{Limitations}

The major limitations of this review were lack of data in some countries and nonvalid data in developing countries. Some papers had poor or unclear information or evaluation. In some cases, it was not possible to find valuable data. Thus, we applied the phrase "not found" for such cases.

\section{Conclusion}

About $50 \%$ to $80 \%$ of sexually active females will be infected with HPV during their lifetime. The global HPV prevalence has been estimated to beabout $11.7 \%$. The major burden of HPV infection is the carcinogenic effect of high-risk HPVs. Since there is no definite treatment for HPV, the high prevalence of genital HPV has been a great concern in the world. At present, vaccination has been introduced as the best prevention and treatment method for HPV infection. If complete effectiveness of vaccination is expected, future vaccines should be multivalent for all described oncogenic HPV types. Nonetheless, these vaccines will be much more expensive than current formulations (14). Although some researchers have reported positive clinical effectiveness of vaccines in reducing malignancy, large population-based clinical studies of these vaccines are necessary to assess the true impact of vaccination $(135,154,155)$. We believe that routine use of HPV vaccines needs much more care and assessment because there are many doubts and questions about these vaccines. 


\section{Conflict of Interests}

The authors declare that they have no competing interests.

\section{References}

1. Trottier H, Franco EL. The epidemiology of genital human papillomavirus infection. Vaccine. 2006 Mar 30;24:S4-15.

2. Yarbrough ML, Burnham CA. The ABCs of STIs: an update on sexually transmitted infections. Clin Chem. 2016;62(6):811-23.

3. Egawa N, Doorbar J. The low-risk papillomaviruses. Virus Res. 2017;231:119-27

4. Haley CT, Mui UN, Vangipuram R, Rady PL, Tyring SK. Human oncoviruses: Mucocutaneous manifestations, pathogenesis, therapeutics, and prevention: Papillomaviruses and Merkel cell polyomavirus. J Am Acad Dermatol. 2019;81(1):1-21.

5. Krzowska-Firych J, Lucas G, Lucas C, Lucas N, Pietrzyk Ł. An overview of Human Papillomavirus (HPV) as an etiological factor of the anal cancer. J Infect Public Health. 2019 Jan-Feb;12(1):1-6.

6. von Knebel Doeberitz M, Prigge ES. Role of DNA methylation in HPV associated lesions. Papillomavirus Res. 2019 Jun;7:180-183.

7. de Martel C, Ferlay J, Franceschi S, Vignat J, Bray F, Forman D, Plummer M. Global burden of cancers attributable to infections in 2008: a review and synthetic analysis. Lancet Oncol. 2012 Jun;13(6):607-15

8. Plummer M, de Martel C, Vignat J, Ferlay J, Bray F, Franceschi S. Global burden of cancers attributable to infections in 2012: a synthetic analysis. Lancet Glob Health. 2016 Sep;4(9):e609-16.

9. de Sanjose S, Quint WG, Alemany L, Geraets DT, Klaustermeier JE, Lloveras B, et al. Human papillomavirus genotype attribution in invasive cervical cancer: a retrospective cross-sectional worldwide study. Lancet Oncol. 2010 Nov;11(11):1048-56.

10. Alizon S, Murall CL, Bravo IG. Why Human Papillomavirus Acute Infections Matter. Viruses. 2017 Oct 10;9(10):293.

11. Schiffman M, Castle PE, Jeronimo J, Rodriguez AC, Wacholder S. Human papillomavirus and cervical cancer. Lancet. 2007 Sep 8;370(9590):890-907

12. Woodman CB, Collins SI, Young LS. The natural history of cervical HPV infection: unresolved issues. Nat Rev Cancer. 2007 Jan;7(1):1122

13. Trimble CL, Piantadosi S, Gravitt P, Ronnett B, Pizer E, Elko A, Wilgus $\mathrm{B}$, et al. Spontaneous regression of high-grade cervical dysplasia: effects of human papillomavirus type and HLA phenotype. Clin Cancer Res. 2005 Jul 1;11(13):4717-23.

14. Rosales R, Rosales C. Immune therapy for human papillomavirusesrelated cancers. World J Clin Oncol. 2014 Dec 10;5(5):1002-19.

15. Koutsky L. Epidemiology of genital human papillomavirus infection. Am J Med. 1997;102(5):3-8

16. Bruni L. The frequency of HPV infection worldwide. https://wwwhpvworldcom/articles/the-frequency-of-hpv-infectionworldwide/. 2020

17. de Sanjosé S, Diaz M, Castellsagué X, Clifford G, Bruni L, Muñoz $\mathrm{N}$, Bosch FX. Worldwide prevalence and genotype distribution of cervical human papillomavirus DNA in women with normal cytology: a meta-analysis. Lancet Infect Dis. 2007 Jul;7(7):453-9.

18. Farahmand M, Moghoofei M, Dorost A, Abbasi S, Monavari SH, Kiani SJ, et al. Prevalence and genotype distribution of genital human papillomavirus infection in female sex workers in the world: a systematic review and meta-analysis. BMC Public Health. 2020;20(1):1455

19. Roden RB, Lowy DR, Schiller JT. Papillomavirus is resistant to desiccation. J Infect Dis. 1997 Oct;176(4):1076-9.

20. Schlecht NF, Burk RD, Nucci-Sack A, Shankar V, Peake K, LordeRollins E, et al. Cervical, anal and oral HPV in an adolescent innercity health clinic providing free vaccinations. PLoS One. 2012;7(5):e37419.

21. Manini I, Montomoli E. Epidemiology and prevention of Human Papillomavirus. Ann Ig. 2018 Jul-Aug;30(4 Supple 1):28-32.

22. Howie HL, Katzenellenbogen RA, Galloway DA. Papillomavirus E6 proteins. Virology. 2009;384(2):324-34.

23. Wise-Draper TM, Wells SI. Papillomavirus E6 and E7 proteins and their cellular targets. Front Biosci. 2008 Jan 1;13:1003-17.

24. Lyu Z, Feng X, Li N, Zhao W, Wei L, Chen Y, et al. Human papillomavirus in semen and the risk for male infertility: a systematic review and meta-analysis. BMC Infect Dis. 2017 Nov 9;17(1):714.

25. Kenter GG, Welters MJ, Valentijn ARP, Lowik MJ, Berends-van der Meer DM, Vloon AP, et al. Vaccination against HPV-16 oncoproteins for vulvar intraepithelial neoplasia. N Engl J Med. 2009 Nov $5 ; 361(19): 1838-47$

26. de Vos van Steenwijk PJ, van Poelgeest MI, Ramwadhdoebe TH, Löwik MJ, Berends-van der Meer DM, et al. The long-term immune response after HPV16 peptide vaccination in women with low-grade pre-malignant disorders of the uterine cervix: a placebo-controlled phase II study. Cancer Immunol Immunother. 2014 Feb;63(2):147-60.

27. van Poelgeest MI, Welters MJ, Vermeij R, Stynenbosch LF, Loof NM, Berends-van der Meer DM, et al. Vaccination against Oncoproteins of HPV16 for Noninvasive Vulvar/Vaginal Lesions: Lesion Clearance Is Related to the Strength of the T-Cell Response. Clin Cancer Res. 2016 May 15;22(10):2342-50.

28. Wang C, Dickie J, Sutavani RV, Pointer C, Thomas GJ, Savelyeva N. Targeting Head and Neck Cancer by Vaccination. Front Immunol. 2018 Apr 23;9:830

29. Spurgeon ME, Lambert PF. Human Papillomavirus and the Stroma: Bidirectional Crosstalk during the Virus Life Cycle and Carcinogenesis. Viruses. 2017 Aug 9;9(8):219.

30. Durzynska J, Lesniewicz K, Poreba E. Human papillomaviruses in epigenetic regulations. Mutat Res Rev Mutat Res. 2017 AprJun;772:36-50.

31. McBride AA, Warburton A. The role of integration in oncogenic progression of HPV-associated cancers. PLoS Pathog. 2017 Apr 6;13(4):e1006211.

32. Doorbar J, Egawa N, Griffin H, Kranjec C, Murakami I. Human papillomavirus molecular biology and disease association. Rev Med Virol. 2015 Mar;25 Suppl 1(Suppl Suppl 1):2-23.

33. World Health O. Human papillomavirus laboratory manual. 1st ed. 2009 ed. Geneva: World Health Organization; 2010.

34. Coser J, Boeira TdR, Fonseca ASK, Ikuta N, Lunge VR. Human papillomavirus detection and typing using a nested-PCR-RFLP assay. Braz J Infect Dis. 2011;15(5):467-72.

35. Carvalho Nde O, del Castillo DM, Perone C, Januário JN, Melo VH, Brasileiro Filho G. Comparison of HPV genotyping by type-specific PCR and sequencing. Mem Inst Oswaldo Cruz. $2010 \mathrm{Feb} ; 105(1): 73-8$.

36. Jalouli M, Jalouli J, Ibrahim SO, Hirsch JM, Sand L. Comparison between single PCR and nested PCR in detection of human papilloma viruses in paraffin-embedded OSCC and fresh oral mucosa. In vivo. 2015;29(1):65-70.

37. Tawe L, Grover S, Narasimhamurthy M, Moyo S, Gaseitsiwe S, Kasvosve I, et al. Molecular detection of human papillomavirus (HPV) in highly fragmented DNA from cervical cancer biopsies using double-nested PCR. MethodsX. 201 8;5:569-78.

38. Romero-Pastrana F. Detection and typing of human papilloma virus by multiplex PCR with type-specific primers. ISRN Microbiol. 2012;2012:186915

39. Kroupis C, Vourlidis N. Human papilloma virus (HPV) molecular diagnostics. Clin Chem Lab Med. 2011 Nov;49(11):1783-99.

40. Molijn A, Kleter B, Quint W, van Doorn LJ. Molecular diagnosis of human papillomavirus (HPV) infections. J Clin Virol. 2005 Mar;32 Suppl 1:S43-51.

41. Nuovo GJ. In situ detection of human papillomavirus DNA after PCR-amplification. Methods Mol Biol. 2011;688:35-46.

42. Venuti A, Paolini F. HPV detection methods in head and neck cancer. Head Neck Pathol. 2012 Jul;6 Suppl 1(Suppl 1):S63-74.

43. Barcellos RB, Almeida SE, Sperhacke RD, Verza M, Rosso F, Medeiros RM, et al. Evaluation of a novel microplate colorimetric hybridization genotyping assay for human papillomavirus. J Virol Methods. 2011 Oct; 177(1):38-43.

44. Chin-Hong PV, Klausner JD. New diagnostic tests for HPV in the developed and the developing world. MLO Med Lab Obs. 2008 Nov;40(11):48, 50, 52-3

45. Poljak M, Kocjan BJ. Commercially available assays for multiplex detection of alpha human papillomaviruses. Expert Rev Anti Infect Ther. 2010 Oct;8(10):1139-62.

46. García-Sierra N, Martró E, Castellà E, Llatjós M, Tarrats A, Bascuñana $\mathrm{E}$, et al. Evaluation of an array-based method for human papillomavirus detection and genotyping in comparison with conventional methods used in cervical cancer screening. J Clin Microbiol. $2009 \mathrm{Jul} ; 47(7): 2165-9$

47. Sun ZR, Ji YH, Zhou WQ, Zhang SL, Jiang WG, Ruan Q. Characteristics of HPV prevalence among women in Liaoning 
province, China. Int J Gynaecol Obstet. 2010 May;109(2):105-9.

48. Lin M, Yang LY, Li LJ, Wu JR, Peng YP, Luo ZY. Genital human papillomavirus screening by gene chip in Chinese women of Guangdong province. Aust N Z J Obstet Gynaecol. 2008 Apr;48(2):189-94.

49. Kim KH, Yoon MS, Na YJ, Park CS, Oh MR, Moon WC. Development and evaluation of a highly sensitive human papillomavirus genotyping DNA chip. Gynecol Oncol. 2006 Jan;100(1):38-43.

50. Klug SJ, Molijn A, Schopp B, Holz B, Iftner A, Quint W, et al. Comparison of the performance of different HPV genotyping methods for detecting genital HPV types. J Med Virol. 2008 Jul;80(7):1264-74.

51. Erali M, Pattison DC, Wittwer CT, Petti CA. Human papillomavirus genotyping using an automated film-based chip array. J Mol Diagn. 2009 Sep; $11(5): 439-45$

52. Oh TJ, Kim CJ, Woo SK, Kim TS, Jeong DJ, Kim MS, et al. Development and clinical evaluation of a highly sensitive DNA microarray for detection and genotyping of human papillomaviruses. $\mathrm{J}$ Clin Microbiol. 2004 Jul;42(7):3272-80.

53. Liu SS, Leung RC, Chan KK, Cheung AN, Ngan HY. Evaluation of a newly developed GenoArray human papillomavirus (HPV) genotyping assay and comparison with the Roche Linear Array HPV genotyping assay. J Clin Microbiol. 2010;48(3):758-64.

54. Oh Y, Bae SM, Kim YW, Choi HS, Nam GH, Han SJ, et al. Polymerase chain reaction-based fluorescent Luminex assay to detect the presence of human papillomavirus types. Cancer Sci. 2007 Apr;98(4):549-54.

55. Jiang HL, Zhu HH, Zhou LF, Chen F, Chen Z. Genotyping of human papillomavirus in cervical lesions by L1 consensus PCR and the Luminex xMAP system. J Med Microbiol. 2006 Jun;55(Pt 6):715-720. 56. Schmitt M, Dondog B, Waterboer T, Pawlita M, Tommasino M, Gheit T. Abundance of multiple high-risk human papillomavirus (HPV) infections found in cervical cells analyzed by use of an ultrasensitive HPV genotyping assay. J Clin Microbiol. 2010;48(1):143-9.

57. Schmitt M, Dondog B, Waterboer T, Pawlita M. Homogeneous amplification of genital human alpha papillomaviruses by PCR using novel broad-spectrum GP5+ and GP6+ primers. J Clin Microbiol. 2008;46(3):1050-9.

58. Schmitt M, Bravo IG, Snijders PJ, Gissmann L, Pawlita M, Waterboer T. Bead-based multiplex genotyping of human papillomaviruses. J Clin Microbiol. 2006;44(2):504-12.

59. Park KS, Kim JY, Ki CS, Lee NY. Comparison of the digene HPV genotyping LQ test and the PANArray HPV genotyping chip for detection of high-risk or probable high-risk human papillomavirus genotypes. Ann Lab Med. 2014 Jul;34(4):279-85.

60. Geraets DT, Lenselink CH, Bekkers RL, van Doorn LJ, Quint WG, Melchers WJ. Universal human papillomavirus genotyping by the digene HPV Genotyping RH and LQ Tests. J Clin Virol. 2011 Apr;50(4):276-80.

61. Roberts I, Ng G, Foster N, Stanley M, Herdman MT, Pett MR, et al. Critical evaluation of HPV16 gene copy number quantification by SYBR green PCR. BMC Biotechnol. 2008;8:57.

62. Mateos ML, Chacón de Antonio J, Rodríguez-Domínguez M, Sanz I, Rubio MD. Evaluación de un sistema de PCR a tiempo real (cobas 4800) para la detección separada de los genotipos 16 y 18 y otros genotipos de alto riesgo del virus del papiloma humano en la prevención del cáncer cervical [Evaluation of a prototype real-time PCR assay for the separate detection of human papilloma virus genotypes 16 and 18 and other high risk human papillomavirus in cervical cancer screening]. Enferm Infecc Microbiol Clin. 2011 JunJul;29(6):411-4. Spanish.

63. Kocjan BJ, Seme K, Poljak M. Comparison of the Abbott RealTime High Risk HPV test and INNO-LiPA HPV Genotyping Extra test for the detection of human papillomaviruses in formalin-fixed, paraffinembedded cervical cancer specimens. J Virol Methods. 2011 Jul;175(1):117-9.

64. Martínez SB, Palomares JC, Artura A, Parra M, Cabezas JL, Romo JM, et al. Comparison of the Cobas 4800 Human Papillomavirus test against a combination of the Amplicor Human Papillomavirus and the Linear Array tests for detection of HPV types 16 and 18 in cervical samples. J Virol Methods. 2012 Mar;180(1-2):7-10.

65. Poljak M, Ostrbenk A. The Abbott RealTime High Risk HPV test is a clinically validated human papillomavirus assay for triage in the referral population and use in primary cervical cancer screening in women 30 years and older: a review of validation studies. Acta Dermatovenerol Alpina, Pannonica, et Adriatica. 2013;22(2):43-7.

66. Heideman DA, Hesselink AT, Berkhof J, van Kemenade F, Melchers WJ, Daalmeijer NF, et al. Clinical validation of the cobas 4800 HPV test for cervical screening purposes. J Clin Microbiol. 2011;49(11):3983-5

67. Cuzick J, Mayrand MH, Ronco G, Snijders P, Wardle J. Chapter 10: New dimensions in cervical cancer screening. Vaccine. 2006;24 Suppl $3: \mathrm{S} 3 / 90-7$

68. Lie AK, Kristensen G. Human papillomavirus E6/E7 mRNA testing as a predictive marker for cervical carcinoma. Expert Rev Mol Diagn. 2008 Jul;8(4):405-15

69. Villa LL, Denny L. CHAPTER 7 Methods for detection of HPV infection and its clinical utility. Int J Gynaecol Obstet. 2006 Nov;94 Suppl 1:S71-S80.

70. Hwang SJ, Shroyer KR. Biomarkers of cervical dysplasia and carcinoma. J Oncol. 2012;2012:507286.

71. Dockter J, Schroder A, Eaton B, Wang A, Sikhamsay N, Morales L, et al. Analytical characterization of the APTIMA HPV Assay. the official publication of the Pan American Society for Clinical Virology. J Clin Virol 2009;45 Suppl 1:S39-47.

72. Player AN, Shen LP, Kenny D, Antao VP, Kolberg JA. Single-copy gene detection using branched DNAA (bDNA) in situ hybridization. J Histochem Cytochem. 2001 May;49(5):603-12.

73. Wang YF. Signal Amplification Techniques: bDNA, Hybrid Capture. In: Tang YW, Stratton CW, editors. Advanced Techniques in Diagnostic Microbiology. Boston, MA: Springer US; 2006. p. 228-42.

74. Shen Y, Gong J, He Y, Cheng G, Okunieff P, Li X. Quantivirus(R) HPV E6/E7 RNA 3.0 assay (bDNA) is as sensitive, but less specific than Hybrid Capture 2 test. J Virol Methods. 2013;187(2):288-93.

75. Lörincz AT. Hybrid Capture method for detection of human papillomavirus DNA in clinical specimens: a tool for clinical management of equivocal Pap smears and for population screening. J Obstet Gynaecol Res. 1996 Dec;22(16):629-36.

76. Hubbard RA. Human papillomavirus testing methods. Arch Pathol Lab Med. 2003 Aug;127(8):940-5.

77. Chaudhary AK, Pandya S, Mehrotra R, Bharti AC, Singh M, Singh M. Comparative study between the Hybrid Capture II test and PCR based assay for the detection of human papillomavirus DNA in oral submucous fibrosis and oral squamous cell carcinoma. Virol J. 2010 Sep 23;7:253.

78. Smeets SJ, Hesselink AT, Speell EJ, Haesevoets A, Snijders PJ, Pawlita $\mathrm{M}$, et al. A novel algorithm for reliable detection of human papillomavirus in paraffin embedde d head and neck cancer specimen. Int J Cancer. 2007 Dec 1;121(11):2465-72.

79. Badaracco G, Venuti A, Morello R, Muller A, Marcante ML. Human papillomavirus in head and neck carcinomas: prevalence, physical status and relationship with clinical/pathological parameters. Anticancer Res. 2000 Mar-Apr;20(2'B):1301-5.

80. Venuti A, Manni V, Morello R, De Marco F, Marzetti F, Marcante ML. Physical state and expression of human papillomavirus in laryngeal carcinoma and surrounding normal mucosa. J Med Virol. 2000 Apr;60(4):396-402.

81. Yeudall WA, Campo MS. Human papillomavirus DNA in biopsies of oral tissues. J Gen Virol. 1991 Jan;72 ( Pt 1):173-6.

82. Mayrand MH, Coutlée F, Hankins C, Lapointe N, Forest P, de Ladurantaye $M$, et al. Detection of human papillomavirus type 16 DNA in consecutive genital samples does not always represent persistent infection as determined by molecular variant analysis. J Clin Microbiol. 2000 Sep;38(9):3388-93.

83. de Sanjosé S, Palefsky J. Cervical and anal HPV infections in HIV positive women and men. Virus Resi. 2002 Nov;89(2):201-11.

84. Mesher D, Stanford E, White J, Findlow J, Warrington R, Das S, et al. HPV Serology Testing Confirms High HPV Immunisation Coverage in England. PloS One. 2016;11(3):e0150107.

85. Dillner J. The serological response to papillomaviruses. Semin Cancer Biol. 1999 Dec;9(6):423-30.

86. Chung MY, Kim YW, Bae SM, Kwon EH, Chaturvedi PK, Battogtokh G, et al. Development of a bead-based multiplex genotyping method for diagnostic characterization of HPV infection. PloS One. 2012;7(2):e32259.

87. Day PM, Thompson CD, Buck CB, Pang YY, Lowy DR, Schiller JT. Neutralization of human papillomavirus with monoclonal antibodies reveals different mechanisms of inhibition. J Virol. 2007 Aug;81(16):8784-92. 
88. Day PM, Pang YY, Kines RC, Thompson CD, Lowy DR, Schiller JT. A human papillomavirus (HPV) in vitro neutralization assay that recapitulates the in vitro process of infection provides a sensitive measure of HPV L2 infection-inhibiting antibodies. Clin Vaccine Immunol. $2012 \mathrm{Jul} ; 19(7): 1075-82$.

89. Draper E, Bissett SL, Howell-Jones R, Edwards D, Munslow G, Soldan K, et al. Neutralization of non-vaccine human papillomavirus pseudoviruses from the A7 and A9 species groups by bivalent HPV vaccine sera. Vaccine. 2011;29(47):8585-90.

90. Li Y, Liu J, Gong L, Sun X, Long W. Combining HPV DNA load with p16/Ki-67 staining to detect cervical precancerous lesions and predict the progression of CIN1-2 lesions. Virol J. 2019 Oct $16 ; 16(1): 117$.

91. Yu L, Fei L, Liu X, Pi X, Wang L, Chen S. Application of p16/Ki-67 dual-staining cytology in cervical cancers. J Cancer. 2019 Jun 2;10(12):2654-2660.

92. Yu L, Wang L, Zhong J, Chen S. Diagnostic value of p16INK4A, Ki-67, and human papillomavirus L1 capsid protein immunochemical staining on cell blocks from residual liquid-based gynecologic cytology specimens. Cancer Cytopathol. $2010 \mathrm{Feb}$ 25;118(1):47-55.

93. Wang HR, Li YC, Guo HQ, Yu LL, Wu Z, Yin J, et al. A cocktail of p16INK4a and Ki-67, p16INK4a and minichromosome maintenance protein 2 as triage tests for human papillomavirus primary cervical cancer screening. Oncotarget. 2017 Aug 3;8(48):83890-83899.

94. Bello JO, Nieva LO, Paredes AC, Gonzalez AM, Zavaleta LR, Lizano M. Regulation of the Wnt/beta-Catenin Signaling Pathway by Human Papillomavirus E6 and E7 Oncoproteins. Viruses. 2015;7(8):4734-55.

95. Talora C, Sgroi DC, Crum CP, Dotto GP. Specific down-modulation of Notch1 signaling in cervical cancer cells is required for sustained HPV-E6/E7 expression and late steps of malignant transformation. Genes Dev. 2002 Sep 1;16(17):2252-63.

96. Bossler F, Hoppe-Seyler K, Hoppe-Seyler F. PI3K/AKT/mTOR Signaling Regulates the Virus/Host Cell Crosstalk in HPV-Positive Cervical Cancer Cells. Int J Mol Sci. 2019 May 3;20(9):2188.

97. Hoppe-Seyler K, Bossler F, Braun JA, Herrmann AL, Hoppe-Seyler F. The HPV E6/E7 Oncogenes: Key Factors for Viral Carcinogenesis and Therapeutic Targets. Trends Microbiol. 2018 Feb;26(2):158-168.

98. Taghizadeh E, Jahangiri S, Rostami D, Taheri F, Renani PG, Taghizadeh H, et al. Roles of E6 and E7 Human Papillomavirus Proteins in Molecular Pathogenesis of Cervical Cancer. Curr Protein Pept Sci. 2019;20(9):926-934

99. Zhang B, Spandau DF, Roman A. E5 protein of human papillomavirus type 16 protects human foreskin keratinocytes from UV B-irradiation-induced apoptosis. Virol J. 2002;76(1):220-31.

100. Wasson CW, Morgan EL, Muller M, Ross RL, Hartley M, Roberts $\mathrm{S}$, et al. Human papillomavirus type 18 E5 oncogene supports cell cycle progression and impairs epithelial differentiation by modulating growth factor receptor signalling during the virus life cycle. Oncotarget. 2017;8(61):103581-600.

101. Venuti A, Paolini F, Nasir L, Corteggio A, Roperto S, Campo MS, et al. Papillomavirus E5: the smallest oncoprotein with many functions. Mol Cancer. 2011 Nov 11;10:140..

102. Altavilla G, Staffieri A, Busatto G, Canesso A, Giacomelli L, Marioni G. Expression of p53, p16INK4A, pRb, p21WAF1/CIP1, p27KIP1, cyclin D1, Ki-67 and HPV DNA in sinonasal endophytic Schneiderian (inverted) papilloma. Acta Otolaryngol. 2009 Nov;129(11):1242-9.

103. Wang X, Wang HK, Li Y, Hafner M, Banerjee NS, Tang S, et al. microRNAs are biomarkers of oncogenic human papillomavirus infections. Proc Natl Acad Sci U S A. 2014 Mar 18;111(11):4262-7.

104. Zamani S, Sohrabi A, Hosseini SM, Rahnamaye-Farzami M, Akbari A. Deregulation of miR-21 and miR-29a in Cervical Cancer Related to HPV Infection. Microrna. 2019;8(2):110-115.

105. Bumrungthai S, Ekalaksananan T, Evans MF, Chopjitt P, Tangsiriwatthana T, Patarapadungkit N, et al. Up-Regulation of miR21 Is Associated with Cervicitis and Human Papillomavirus Infection in Cervical Tissues. PloS One. 2015;10(5):e0127109.

106. Myklebust MP, Bruland O, Fluge Ø, Skarstein A, Balteskard L, Dahl O. MicroRNA-15b is induced with E2F-controlled genes in HPV-related cancer. Br J Cancer. 2011 Nov 22;105(11):1719-25.

107 Lajer CB, Garnæs E, Friis-Hansen L, Norrild B, Therkildsen MH, Glud M, et al. The role of miRNAs in human papilloma virus (HPV)associated cancers: bridging between HPV-related head and neck cancer and cervical cancer. Br J Cancer. 2017 Aug 22;117(5):e2.
108. Coimbra EC, DA Conceição Gomes Leitão M, Júnior MR, DE Oliveira TH, DA Costa Silva Netto J, DE Freitas AC. Expression Profile of MicroRNA-203 and its $\Delta \mathrm{Np} 63$ Target in Cervical Carcinogenesis: Prospects for Cervical Cancer Screening. Anticancer Res. 2016 Aug;36(8):3939-46.

109. Park S, Kim J, Eom K, Oh S, Kim S, Kim G, et al. microRNA-944 overexpression is a biomarker for poor prognosis of advanced cervical cancer. BMC Cancer. 2019;19(1):419.

110. Fang H, Shuang D, Yi Z, Sheng H, Liu Y. Up-regulated microRNA-155 expression is associated with poor prognosis in cervical cancer patients. Biomed Pharmacother. 2016;83:64-9.

111. Wang F, Li Y, Zhou J, Xu J, Peng C, Ye F, et al. miR-375 is downregulated in squamous cervical cancer and inhibits cell migration and invasion via targeting transcription factor SP1. Am J Pathol. 2011;179(5):2580-8.

112. Jayamohan S, Kannan M, Moorthy RK, Rajasekaran N, Jung HS, Shin YK, et al. Dysregulation of miR-375/AEG-1 Axis by Human Papillomavirus 16/18-E6/E7 Promotes Cellular Proliferation, Migration, and Invasion in Cervical Cancer. Front Oncol. 2019 Sep 9;9:847.

113. Stanley M. Pathology and epidemiology of HPV infection in females. Gynecol Oncol. 2010 May;117(2 Suppl):S5-10..

114. Garland SM, Steben M, Sings HL, James M, Lu S, Railkar R, et al. Natural history of genital warts: analysis of the placebo arm of 2 randomized phase III trials of a quadrivalent human papillomavirus (types 6, 11, 16, and 18). Vaccine. 2009;199(6):805-14.

115. Hasanzadeh M, Rejali M, Mehramiz M, Akbari M, Mousavi Seresht L, Yazdandoost Y, et al. The interaction of high and low-risk human papillomavirus genotypes increases the risk of developing genital warts: A population-based cohort study. J Cell Biochem. 2019;120(8):12870-4.

116. Mougin C, Dalstein V, Prétet JL, Gay C, Schaal JP, Riethmuller D. Epidémiologie des infections cervicales à papillomavirus. Acquisitions récentes [Epidemiology of cervical papillomavirus infections. Recent knowledge]. Presse Med. 2001 Jun 9;30(20):101723. [French]

117. Batista CS, Atallah AN, Saconato H, da Silva EM. 5-FU for genital warts in non-immunocompromised individuals. Cochrane Database Syst Rev. 2010 Apr 14;2010(4):CD006562

118. Blomberg M, Friis S, Munk C, Bautz A, Kjaer SK. Genital warts and risk of cancer: a Danish study of nearly 50000 patients with genital warts. J Infect Dis. 2012 May 15;205(10):1544-53.

119 Baykal C, Yazganoğlu KD. Skin Appendage Tumors. In: Clinical Atlas of Skin Tumors. Springer, Berlin, Heidelberg. 2014.

120. Hogewoning CJ, Bleeker MC, van den Brule AJ, Voorhorst FJ, Snijders PJ, Berkhof J, et al. Condom use promotes regression of cervical intraepithelial neoplasia and clearance of human papillomavirus: a randomized clinical trial. Int J Cancer. 2003 Dec 10;107(5):811-6.

121. Ferenczy A. Epidemiology and clinical pathophysiology of condylomata acuminata. Am J Obstet Gynecol. 1995 Apr;172(4 Pt 2):1331-9.

122. Workowski KA, Berman SM. Sexually transmitted diseases treatment guidelines. 2006;55(11):38-42.

123. Nathan M, Hickey N, Mayuranathan L, Vowler SL, Singh N. Treatment of anal human papillomavirus-associated disease: a long term outcome study. Int J STD AIDS. 2008 Jul;19(7):445-9.

124. Berry JM, Jay N, Cranston RD, Darragh TM, Holly EA, Welton ML, et al. Progression of anal high-grade squamous intraepithelial lesions to invasive anal cancer among HIV-infected men who have sex with men. Int J Cancer . 2014;134(5):1147-55.

125. Fathi R, Tsoukas MM. Genital warts and other HPV infections: Established and novel therapies. Clin Dermatol . 2014;32(2):299-306.

126. Agarwal A, Mulgund A, Hamadla A, Chyatte MR. A unique view on male infertility around the globe. Reprod Biol Endocrinol. 2015;13(1):37.

127. Krausz C. Male infertility: pathogenesis and clinical diagnosis. Best Pract Res Clin Endocrinol Metab. 2011;25(2):271-85.

128. Nasseri S, Monavari SH, Keyvani H, Nikkhoo B, Vahabpour Roudsari R, Khazeni M. The prevalence of Human Papilloma Virus (HPV) infection in the oligospermic and azoospermic men. Med J Islam Repub Iran. 2015;29(1):1001-6.

129. Kyrgiou M, Athanasiou A, Paraskevaidi M, Mitra A, Kalliala I, Martin-Hirsch P, et al. Adverse obstetric outcomes after local treatment for cervical preinvasive and early invasive disease according 
to cone depth: systematic review and meta-analysis. BMJ. 2016;354:i3633

130. Zuo Z, Goel S, Carter JE. Association of cervical cytology and HPV DNA status during pregnancy with placental abnormalities and preterm birth. Am J Clin Pathol. 2011;136(2):260-5

131. Luttmer R, Dijkstra MG, Snijders PJ, Hompes PG, Pronk DT, Hubeek I, et al. Presence of human papillomavirus in semen in relation to semen quality. Hum Reprod. 2016;31(2):280-6.

132. Jeršovienė V, Gudlevičienė Ž, Rimienė J, Butkauskas D. Human Papillomavirus and Infertility. Medicina (Kaunas). 2019;55(7):377.

133. Wierzbicka M, Józefiak A, Szydłowski J, Marszałek A, Stankiewicz C, Hassman-Poznańska E, et al. Recommendations for the diagnosis of human papilloma virus (HPV) high and low risk in the prevention and treatment of diseases of the oral cavity, pharynx and larynx. Guide of experts PTORL and KIDL. BMC Infect Dis. 2013;67(3):113-34.

134. Yang A, Jeang J, Cheng $\mathrm{K}$, Cheng $\mathrm{T}$, Yang B, Wu TC, et al. Current state in the development of candidate therapeutic HPV vaccines. Expert Rev Vaccines. 2016;15(8):989-1007.

135. Laurent JS, Luckett R, Feldman S. HPV vaccination and the effects on rates of HPV-related cancers. Curr Probl Cancer. 2018;42(5):493506.

136. Dillner J, Arbyn M, Unger E, Dillner LJC, Immunology E. Monitoring of human papillomavirus vaccination. Clin Exp Immunol. 2011;163(1):17-25.

137. Kleinsorge F, Schmidmayr M. Humane Papillomavirusinfektion bei Frauen. Gynäkol Onkol. 2018;57(12):1445-51

138. Yang A, Farmer E, Wu TC, Hung CF. Perspectives for therapeutic HPV vaccine development. J Biomed Sci. 2016;23(1):75.

139. Steben M, Thompson MT, Rodier C, Mallette N, Racovitan V, DeAngelis F, et al. A review of the impact and effectiveness of the quadrivalent human papillomavirus vaccine: 10 years of clinical experience in Canada. J Obstet Gynaecol Can. 2018;40(12):1635-45.

140. Paavonen J, Naud P, Salmerón J, Wheeler CM, Chow SN, Apter D, et al. Efficacy of human papillomavirus (HPV)-16/18 AS04adjuvanted vaccine against cervical infection and precancer caused by oncogenic HPV types (PATRICIA): final analysis of a double-blind, randomised study in young women. Lancet. 2009;374(9686):301-14.

141. Clifford GM, Rana RK, Franceschi S, Smith JS, Gough G, Pimenta $\mathrm{JM}$, et al. Human papillomavirus genotype distribution in low-grade cervical lesions: comparison by geographic region and with cervical cancer. Cancer Epidemiol Biomarkers Prev. 2005;14(5):1157-64

142. Smith JS, Lindsay L, Hoots B, Keys J, Franceschi S, Winer R, et al. Human papillomavirus type distribution in invasive cervical cancer and high-grade cervical lesions: a meta-analysis update. Int $\mathrm{J}$ Cancer. 2007;121(3):621-32.

143. Ikeda SI, Hineno A, Ozawa K, Kinoshita TJIr. Suspected adverse effects after human papillomavirus vaccination: a temporal relationship. Drug Saf. 2018;66(6):723-5.

144. WHO. https://www.who.int/immunization/hpv/deliver/en/. 2020.

145. De Vuyst H, Clifford GM, Nascimento MC, Madeleine MM, Franceschi S. Prevalence and type distribution of human papillomavirus in carcinoma and intraepithelial neoplasia of the vulva, vagina and anus: a meta-analysis. Int J Cancer. 2009;124(7):1626-36.

146. Hernandez BY, Wilkens LR, Zhu X, Thompson P, McDuffie K, Shvetsov YB, et al. Transmission of human papillomavirus in heterosexual couples. Emerg Infect Dis. 2008;14(6):888.

147. Baldwin JI, Baldwin JD. Heterosexual anal intercourse: an understudied, high-risk sexual behavior. Arch Sex Behav. 2000;29(4):357-73

148. Zhen S, Li X, Biochemistry. Oncogenic human papillomavirus: application of CRISPR/Cas9 therapeutic strategies for cervical cancer. Cell Physiol Biochem. 2017;44(6):2455-66.

149. Šarenac T, Mikov M. Cervical cancer, different treatments and importance of bile acids as therapeutic agents in this disease. Front Pharmacol. 2019;10.

150. Barbosa MS, Vass WC, Lowy DR, Schiller JT. In vitro biological activities of the E6 and E7 genes vary among human papillomaviruses of different oncogenic potential. J Virol. 1991;65(1):292-8.

151. Halbert C, Demers G, Galloway D. The E7 gene of human papillomavirus type 16 is sufficient for immortalization of human epithelial cells. J Virol. 1991;65(1):473-8.

152. Lacey CJN, Guimera N, Garland SM. Chapter 10 - Low-risk Human Papillomavirus: Genital Warts, Cancer and Respiratory Papillomatosis. In: Jenkins D, Bosch FX, editors. Human
Papillomavirus: Academic Press; 20120. p. 165-78.

153. Meites E, Szilagyi PG, Chesson HW, Unger ER, Romero JR, Markowitz LE. Human papillomavirus vaccination for adults: Updated recommendations of the Advisory Committee on Immunization Practices. 2019;19(11):3202-6.

154. Rodriguez AM, Do TQN, Goodman M, Schmeler KM, Kaul S, Kuo YF. Human papillomavirus vaccine interventions in the US: A systematic review and meta-analysis. Am J Prev Med. 2019 Apr;56(4):591-602

155. Di Tucci C, Schiavi MC, Faiano P, D’Oria O, Prata G, Sciuga V, et al. Therapeutic vaccines and immune checkpoints inhibition options for gynecological cancers. Crit Rev Oncol Hematol. 2018;128:30-42.

156. https://www.hpvcentre.net/. 2020 .

157. Clifford G, Franceschi S, Diaz M, Munoz N, Villa L. Chapter 3: HPV type-distribution in women with and without cervical neoplastic diseases. Vaccine 24. S3/26-34, https://doi. org/10.1016/j. vaccine. 2006.05. 026; 2006.

158. Alkatout I, Schubert M, Garbrecht N, Weigel MT, Jonat W, Mundhenke $\mathrm{C}$, et al. Vulvar cancer: epidemiology, clinical presentation, and management options. Int $\mathrm{J}$ Womens Health 2015;7:305.

159. Rajaram S, Maheshwari A, Srivastava AJBP, Obstetrics RC. Staging for vaginal cancer. Best Pract Res Clin Obstet Gynaecol. 2015;29(6):822-32

160. Siegel RL, Miller KD, Jemal A. Cancer statistics, 2016. CA Cancer J Clin. 2016;66(1):7-30.

161. Watson M, Saraiya M, Wu X. Update of HPV-associated female genital cancers in the United States, 1999-2004. J Womens Health (Larchmt). 2009;18(11):1731-8

162. Insinga RP, Liaw KL, Johnson LG, Madeleine MM. A systematic review of the prevalence and attribution of human papillomavirus types among cervical, vaginal, and vulvar precancers and cancers in the United States. Cancer Epidemiol Biomarkers Prev. 2008;17(7):1611-22.

163. Uronis HE, Bendell JC. Anal cancer: an overview. Oncologist. 2007;12(5):524-34.

164. Sobhani I, Vuagnat A, Walker F, Vissuzaine C, Mirin B, Hervatin $\mathrm{F}$, et al. Prevalence of high-grade dysplasia and cancer in the anal canal in human papillomavirus-infected individuals. Gastroenterology. 2001;120(4):857-66.

165. Cancer Control Strategy for Poland 2015-2024. 10 June 2014 Avaliable Online at: http://www.walkazrakiem.pl/sites/default/ files/library/files/polish cancer control strategy 0.pdf

166. https://www.cdc.gov/cancer/hpv/statistics/anal.htm

167. Boda D, Docea AO, Calina D, Ilie MA, Caruntu C, Zurac S, et al. Human papilloma virus: Appreheniding the link with carcinogenesis and unveiling new research avenues. Int J Oncol. 2018;52(3):637-55.

168. Ferlay J, Shin HR, Bray F, Forman D, Mathers C, Parkin DMJijoc. Estimates of worldwide burden of cancer in 2008: GLOBOCAN 2008. Int J Cancer. 2010;127(12):2893-91'7.

169. Ludmir EB, Stephens SJ, Palta M, Willett CG, Czito BG. Human papillomavirus tumor infection in esophageal squamous cell carcinoma. J Gastrointest Oncol. 2015;6(3):287.

170. Liu H, Li J, Diao M, Cai Z, Yang J, Zeng Y. Statistical analysis of human papillomavirus in a subset of upper aerodigestive tract tumors J Med Virol. 2013;85(10):1775-85

171. Enzinger PC, Mayer R. Esophageal cancer. N Engl J Med. 2003;349(23):2241-52.

172. Wang X, Tian X, Liu F, Zhao Y, Sun M, Chen D, et al. Detection of HPV DNA in esophageal cancer specimens from different regions and ethnic groups: a descriptive studly. BMC Cancer. 2010;10(1):19.

173. Torre LA, Bray F, Siegel RL, Ferlay J, Lortet-Tieulent J, Jemal A. Global cancer statistics. CA Cancer J Clin. 2012. 2015;65(2):87-108.

174. Siegel R, DeSantis C, Jemal A. Colorectal cancer statistics, 2014. CA Cancer J Clin. 2014;64(2):104-117.

175. Lorenzon L, Mazzetta F, Pilozzi E, Uggeri G, Torrisi MR, Ferri M, et al. Human papillomavirus does not have a causal role in colorectal carcinogenesis. World J Gastroenterol. 2015;21(1):342.

176. Bodaghi S, Yamanegi K, Xiao S-, Da Costa M, Palefsky JM, Zheng ZM. Colorectal papillomavirus infiection in patients with colorectal cancer. Clin Cancer Res. 2005;11(8)):2862-7.

177. Miller KD, Siegel RL, Lin CC, Mariotto AB, Kramer JL, Rowland $\mathrm{JH}$, et al. Cancer treatment and survivorship statistics, 2016. CA Cancer J Clin. 2016;66(4):271-89.

178. Quinn M, Babb PJBi. Patterns and trends in prostate cancer 
incidence, survival, prevalence and mortality. Part I: international comparisons. BJU Int. 2002;90(2):162-73.

179. Grönberg H. Prostate cancer epidemiology. Lancet. 2003;361(9360):859-64.

180. Bae JM. Human papillomavirus 16 infection as a potential risk factor for prostate cancer: an adaptive meta-analysis. Epidemiol Health. 2015;37.

181. Hsing AW, Tsao L, Devesa SS. International trends and patterns of prostate cancer incidence and mortality. Int J Cancer. 2000;85(1):60-7.

182. Thuener JE. Urologic Malignancies. Prim Care. 2019;46(2):275-85.

183. Cai T, Mazzoli S, Meacci F, Nesi G, Geppetti P, Malossini G, et al. Human papillomavirus and non-muscle invasive urothelial bladder cancer: potential relationship from a pilot study. Urol Int. 2011;25(2):485-9.

184. Khaled HM, Bahnassi AA, Zekri A-RN, Kassem HA, Mokhtar N, editors. Correlation between p53 mutations and HPV in bilharzial bladder cancer. Urologic Oncology: Seminars and Original Investigations. Urol Oncol. 2003, 21(5):334-341

185. Mvula M, Iwasaka T, Iguchi A, Nakamura S, Masaki Z, Sugimori H. Do human papillomaviruses have a role in the pathogenesis of bladder carcinoma? J Urol. 1996;155(2):471-4.

186. Pashos CL, Botteman MF, Laskin BL, Redaelli A. Bladder cancer: epidemiology, diagnosis, and management. Cancer Pract. 2002;10(6):311-22.

187. Bryant P, Davies P, Wilson D. Detection of human papillomavirus DNA in cancer of the urinary bladder by in situ hybridisation. Br J Urol. 1991;68(1):49-52.

188. Purdue MP, Devesa SS, Sigurdson AJ, McGlynn KA. International patterns and trends in testis cancer incidence. Int $\mathrm{J}$ Cancer. 2005;115(5):822-7.

189. Yousif L, Hammer GP, Blettner M, Zeeb H. Testicular cancer and viral infections: A systematic literature review and meta-analysis. J. Med. Virol. 2013;85(12):2165-75.

190. Strickler H, Schiffman M, Shah K, Rabkin C, Schiller J, Wacholder $\mathrm{S}$, et al. A survey of human papillomavirus 16 antibodies in patients with epithelial cancers. Cancer Epidemiol. 1998;7(4):305-13.

191. Kondoh G, Murata Y, Aozasa K, Yutsudo M, Hakura A. Very high incidence of germ cell tumorigenesis (seminomagenesis) in human papillomavirus type 16 transgenic mice. J Virol. 1991;65(6):3335-9.

192. Bleeker M, Heideman D, Snijders P, Horenblas S, Dillner J, Meijer C. Penile cancer: epidemiology, pathogenesis and prevention. World J Urol. 2009;27(2):141.

193. McCance DJ, Kopan R, Fuchs E, Laimins LAJPotNAoS. Human papillomavirus type 16 alters human epithelial cell differentiation in vitro. Proc Natl Acad Sci U S A. 1988;85(19):7169-73.

194. Hakenberg OW, Compérat EM, Minhas S, Necchi A, Protzel C, Watkin N. EAU guidelines on penile cancer: 2014 update. Eur Urol. 2015;67(1):142-50.

195. Marur S, Forastiere AA, editors. Head and neck cancer: changing epidemiology, diagnosis, and treatment. Mayo Clinic Proceedings. Mayo Clin Proc. 2008 Apr;83(4):489-501.

196. Gillison ML, Broutian T, Pickard RK, Tong ZY, Xiao W, Kahle L, et al. Prevalence of oral HPV infection in the United States, 20092010. JAMA. 2012;307(7):693-703.

197. Curado MP, Hashibe M. Recent changes in the epidemiology of head and neck cancer. Curr Opin Oncol. 2009;21(3):194-200.

198. Karia PS. Epidemiology and outcomes of cutaneous squamous cell carcinoma. High-Risk Cutaneous Squamous Cell Carcinoma: Springer; 2016. p. 3-28.

199. Karia PS, Han J, Schmults CD. Cutaneous squamous cell carcinoma: estimated incidence of disease, nodal metastasis, and deaths from disease in the United States, 2012. J Am Acad Dermatol. 2013;68(6):957-66.

200. Gewirtzman A, Bartlett B, Tyring S. Epidermodysplasia verruciformis and human papilloma virus. Curr Opin Infect Dis. 2008;21(2):141-6.

201. Ramoz N, Rueda LA, Bouadjar B, Montoya LS, Orth G, Favre M. Mutations in two adjacent novel genes are associated with epidermodysplasia verruciformis. Nat Genet. 2002;32(4):579-81.

202. Satterwhite CL, Torrone E, Meites E, Dunne EF, Mahajan R, Ocfemia MCB, et al. Sexually transmitted infections among US women and men: prevalence and incidence estimates, 2008. Sex Transm Dis. 2013;40(3):187-93.

203. Moscicki AB. Impact of HPV infection in adolescent populations. J Adolesc Health. 2005;37(6):S3-S9.
204. Wright Jr TC, Massad LS, Dunton CJ, Spitzer M, Wilkinson EJ, Solomon D, et al. 2006 consensus guidelines for the management of women with cervical intraepithelial neoplasia or adenocarcinoma in situ. Am J Obstet Gynecol. 2007;197(4):340-5.

205. Tainio K, Athanasiou A, Tikkinen KA, Aaltonen R, Cárdenas J, Glazer-Livson $\mathrm{S}$, et al. Clinical course of untreated cervical intraepithelial neoplasia grade 2 under active surveillance: systematic review and meta-analysis. BMJ. 2018:360:k499.

206. Grce M, Mravak-Stipetić M. Human papillomavirus-associated diseases. Clin Dermatol. 2014;32(2):253-8.

207. Bruni L, Diaz M, Castellsagué M, Ferrer E, Bosch FX, de Sanjosé S. Cervical human papillomavirus prevalence in 5 continents: metaanalysis of 1 million women with normal cytological findings. J Infect Dis. 2010;202(12):1789-99.

208. Skapa P, Robová H, Rob L, Zámečník J. Review of precancerous vulvar lesions. Cesk Patol. 2012;48(1):15-21.

209. Rakislova N, Saco A, Sierra A, del Pino M, Ordi J. Role of human papillomavirus in vulvar cancer. Adv Anat Pathol. 2017;24(4):201-14.

210. Nelson EL, Bogliatto F, Stockdale CKJCo, gynecology. Vulvar intraepithelial neoplasia (VIN) and condylomata. Clin Obstet Gynecol. 2015;58(3):512-25.

211. Miles B, Safran HP, Monk B. Therapeutic options for treatment of human papillomavirus-associated cancers-novel immunologic vaccines: Gynecol Oncol Res Pract. ADXS11-001. 2017;4(1):10.

212. Lytwyn A, Salit IE, Raboud J, Chapman W, Darragh T, Winkler B, et al. Interobserver agreement in the interpretation of anal intraepithelial neoplasia. Cancer. 20105;103(7):1447-56.

213. Levi FJEJoC. Cancer incidence in five continents, vol. VI: A Review by Fabio Levi. Eur J Cancer .1993;29(16):2315-9.

214. Ouhoummane N, Steben M, Coutlee F, Vuong T, Forest P, Rodier C, et al. Squamous anal cancer: patient characteristics and HPV type distribution. Cancer Epidemiol .2013;37(6):807-12.

215. Martin D, Balermpas P, Winkelmann R, Rödel F, Rödel C, Fokas E. Anal squamous cell carcinoma-State of the art management and future perspectives. Cancer Treat Rev. 2018;65:11-21.

216. Bucchi D, Stracci F, Buonora N, Masanotti G. Human papillomavirus and gastrointestinal cancer: A review. World J Gastroenterol .2016;22(33):7415.

217. Voeten D, Goedegebuure R, Heineman D, Daams F. Nonmetastatic oesophageal cancer: diagnosis and treatment. Ned Tijdschr Geneeskd .2019;163.

218. Salepci T, Yazici H, Dane F, Topuz E, Dalay N, Onat H, et al. Detection of human papillomavirus DNA by polymerase chain reaction and southern blot hybridization in colorectal cancer patients. J BUON .2009; 14(3):495-9.

219. Navarro M, Nicolas A, Ferrandez A, Lanas A. Colorectal cancer population screening programs worlldwide in 2016: An update. World J Gastroenterol .2017;23(20):3632.

220. Kuipers EJ, Grady WM, Lieberman D, Seufferlein T, Sung JJ, Boelens PG, et al. Colorectal cancer. Nat Rev Dis Primers. 2015;1:15065

221. Tolstov Y, Hadaschik B, Pahernik S, Hohenfellner M, Duensing S, editors. Human papillomaviruses in urological malignancies: a critical assessment. In Urologic Oncology: Seminars and Original Investigations 2014 Jan 1 (Vol. 32, No. 1, pp. 46-e19). Elsevier.

222. Jimenez-Pacheco A, Exposito-Ruiz M, Arrabal-Polo MA, LopezLuque A. Meta-analysis of studies analyzing the role of human papillomavirus in the development of bladder carcinoma. Korean J Urol. 2012:53(4):240-7.

223. Chou R, Dana T. Screening adullts for bladder cancer: a review of the evidence for the US preventive services task force. Ann Intern Med. 2010;153(7):461-8.

224. Kamat AM. Bladder cancer: 2017 and beyond. Indian J Urol. 2017;33(2):104-5.

225. Bochner B, Hansel D, Efstathiou J, Konety B, Lee C, McKiernan J, et al. Urinary bladder. 2017:757.

226. Garolla A, Pizzol D, Bertoldo A, Ghezzi M, Carraro U, Ferlin A, et al. Testicular cancer and HPV semen infection. Front Endocrinol (Lausanne). 2012;3:172.

227. Ilic D, Misso ML. Screening for testicular cancer. Cochrane Database Syst Rev. 2011 Feb 16;(2):CD007853.

228. Dieckmann KP, Frey U, Lock G. Contemporary diagnostic work-up of testicular germ cell tumours. Nat Rev Urol. 2013;10(12):703.

229. Cheng L, Albers P, Berney DM, Feldman DR, Daugaard G, Gilligan T, et al. Testicular cancer. Nat Rev Dis Primers. 2018;4(1):1- 
24.

230. Farhadi A, Behzad-Behbahani A, Geramizadeh B, Sekawi Z, Rahsaz M, Sharifzadeh S. High-risk human papillomavirus infection in different histological subtypes of renal cell carcinoma. J Med Virol. 2014;86(7):1134-44.

231. Rotola A, Monini P, di Luca D, Savioli A, Simone R, Secchiero P, et al. Presence and physical state of HPV DNA in prostate and urinary-tract tissues. Int J Cancer. 1992;52(3):359-65.

232. Khoury JD, Tannir NM, Williams MD, Chen Y, Yao H, Zhang J, et al. Landscape of DNA virus associations across human malignant cancers: analysis of 3,775 cases using RNA-Seq. J Virol. 2013;87(16):8916-26.

233. Herts BR, Silverman SG, Hindman NM, Uzzo RG, Hartman RP, Israel GM, et al. Management of the incidental renal mass on CT: a white paper of the ACR Incidental Findings Committee. J Am Coll Radiol. 2018;15(2):264-73.

234. Giuliano AR, Lee JH, Fulp W, Villa LL, Lazcano E, Papenfuss $\mathrm{MR}$, et al. Incidence and clearance of genital human papillomavirus infection in men (HIM): a cohort study. Lancet. 2011;377(9769):93240.

235. Sievert KD, Dräger DL, Köhn FM, Milerski S, Protzel C, Hakenberg O. Peniskarzinom: Diagnose und Staging. Der Urologe. 2018;57(4):418-22.

236. Schlenker B, Schneede P. The Role of Human Papilloma Virus in Penile Cancer Prevention and New Therapeutic Agents. Eur Urol Focus. 2019;5(1):42-5.

237. Johnston MJ, Nigam R. Recent advances in the management of penile cancer. F1000Research 2019, 8(F1000 Faculty Rev):558 Last updated: 26 APR 2019;8.

238. Spiess PE, Dhillon J, Baumgarten AS, Johnstone PA, Giuliano AR. Pathophysiological basis of human papillomavirus in penile cancer: Key to prevention and delivery of more effective therapies. CA Cancer J Clin. 2016;66(6):481-95.

239. Crispen PL, Mydlo JH. Penile intraepithelial neoplasia and other premalignant lesions of the penis. Urol Clin North Am. 2010;37(3):335-42.

240. Dayyani F, Etzel CJ, Liu M, Ho CH, Lippman SM, Tsao AS, et al. Meta-analysis of the impact of human papillomavirus (HPV) on cancer risk and overall survival in head and neck squamous cell carcinomas (HNSCC). Head Neck Oncol. 2010;2(1):15.

241. Chen AM, Felix C, Wang PC, Hsu S, Basehart V, Garst J, et al. Reduced-dose radiotherapy for human papillomavirus-associated squamous-cell carcinoma of the oropharynx: a single-arm, phase 2 study. Lancet Oncol. 2017;18(6):803-11.

242. Wagner S, Reder H, Sharma S, Würdemann N, Wittekindt C, Klußmann J. Das HPV-getriebene Oropharynxkarzinom-Inzidenz, Trends, Diagnose und Therapie. Laryngorhinootologie. 2018;57(12):1457-63.

243. Kim KY, Lewis Jr JS, Chen ZJT. Current status of clinical testing for human papillomavirus in oropharyngeal squamous cell carcinoma. J Pathol Clin Res October 2018; 4: 213-226.

244. Kobayashi K, Hisamatsu K, Suzui N, Hara A, Tomita H, Miyazaki T. A review of HPV-related head and neck cancer. J Clin Med. 2018;7(9):241.

245. Kabir S, Schmults CD, Ruiz ES. A review of cutaneous squamous cell carcinoma epidemiology, diagnosis, and management. Int $\mathrm{J}$ Cancer Manag. 2018;11(1).

246. Kaliterna V, Barisic Z. Genital human papillomavirus infections. Front Biosci (Landmark Ed). 2018;6:8. 